\title{
Functional roles and networks of non- coding RNAs in the pathogenesis of neurodegenerative diseases
}

\author{
Yi-Ying $\mathrm{Wu}^{1}$ and Hung-Chih $\mathrm{Kuo}^{1,2^{*}}$
}

\begin{abstract}
Recent transcriptome analyses have revealed that noncoding RNAs (ncRNAs) are broadly expressed in mammalian cells and abundant in the CNS, with tissue and cell type-specific expression patterns. Moreover, ncRNAs have been found to intricately and dynamically regulate various signaling pathways in neurodegeneration. As such, some antisense transcripts and microRNAs are known to directly affect neurodegeneration in disease contexts. The functions of ncRNAs in pathogenesis are unique for each disorder, as are the pertinent networks of ncRNA/miRNA/ mRNA that mediate these functions. Thus, further understanding of ncRNA biogenesis and effects might aid the discovery of diagnostic biomarkers or development of effective therapeutics for neurodegenerative disorders. Here, we review the ncRNAs that have so far been identified in major neurodegenerative disease etiology and the mechanisms that link ncRNAs with disease-specific phenotypes, such as HTT aggregation in HD, a-synuclein in PD, and $A \beta$ plaques and hyperphosphorylated Tau in AD. We also summarize the known IncRNA/miRNA/mRNA networks that participate in neurodegenerative diseases, and we discuss ncRNA-related treatments shown to delay disease onset and prolong lifespan in rodent models.
\end{abstract}

Keywords: Noncoding RNAs (ncRNAs), MicroRNAs (miRNAs), Long non-coding RNAs (IncRNAs), Neurodegenerative diseases, Motor neuron diseases, Central nervous system (CNS), Huntington's disease (HD), Parkinson's disease (PD), Alzheimer's disease (AD)

\section{Introduction}

The mammalian genome contains sequences for both protein-coding RNAs (mRNAs) and non-coding RNAs (ncRNAs). Since proteins represent the primary functional output of genetic information, mRNAs have been far more well-studied than their non-coding counterparts. However, over the past decades, functional interrogation of ncRNAs has slowly expanded, deepening our understanding of many biological processes. The diverse catalog of known ncRNAs includes long non-coding

\footnotetext{
* Correspondence: kuohuch@gate.sinica.edu.tw

${ }^{1}$ Institute of Cellular and Organismic Biology, Academia Sinica, No. 128, Sec.

2, Academia Road, Nankang, Taipei 11529, Taiwan

${ }^{2}$ Graduate Institute of Medical Genomics and Proteomics, College of

Medicine, National Taiwan University, Taipei, Taiwan
}

RNAs (lncRNAs; longer than 200 nucleotides), circular RNAs (circRNAs; generated from pre-mRNA backsplicing), small noncoding microRNAs (miRNAs; around 21-25 nucleotides), and natural antisense transcripts (NATs; generated by transcription in the opposite direction to protein coding transcripts). Although most ncRNAs cannot be translated into protein, many function in the regulation of important biological processes by modulating transcription and post-translational modifications [reviewed in [1]]. Among the subtypes of ncRNAs, microRNAs are known to influence many aspects of metazoan biology primarily by mediating mRNA stability and preventing translation [reviewed in [2]]. NATs also interfere with stability of the corresponding sense transcript and affect protein translation and

C C The Author(s). 2020 Open Access This article is licensed under a Creative Commons Attribution 4.0 International License, which permits use, sharing, adaptation, distribution and reproduction in any medium or format, as long as you give appropriate credit to the original author(s) and the source, provide a link to the Creative Commons licence, and indicate if changes were made. The images or other third party material in this article are included in the article's Creative Commons licence, unless indicated otherwise in a credit line to the material. If material is not included in the article's Creative Commons licence and your intended use is not permitted by statutory regulation or exceeds the permitted use, you will need to obtain permission directly from the copyright holder. To view a copy of this licence, visit http://creativecommons.org/licenses/by/4.0/ The Creative Commons Public Domain Dedication waiver (http://creativecommons.org/publicdomain/zero/1.0/) applies to the data made available in this article, unless otherwise stated in a credit line to the data. 
function. Notably, some NATs may be translated and function as dominant negatives. LncRNAs are reported to coordinate chromosome architecture and regulate gene transcription during development and human diseases [3, 4]. LncRNAs also post-transcriptionally regulate gene expression as miRNA decoys or by trapping mRNAs in nuclear bodies and stress granules. A subset of lncRNAs interferes with translation by disrupting ribosome recruitment and preventing protein phosphorylation [1]. Finally, circRNAs are generated from coding genes via back-splicing, i.e., joining of the downstream 5'SS with the upstream 3'SS of an exon. CircRNAs are relatively stable compared to their linear cognates due to a lack of $5^{\prime}$ caps and $3^{\prime}$ tails. Functionally, circRNAs may act as RNA or protein decoys to regulate RNA stability and protein function. The most well-known function of circRNAs is that of a miRNA sponge, which is defined as a scaffold containing multiple binding sites for a specific miRNA. Binding of an miRNA to the scaffold prevents interaction of the sequestered miRNA with its target RNA transcripts. Thus, many circRNAs can affect mRNA stability by regulating miRNA targeting. CircRNAs may also interfere with protein function, giving rise to unique peptides [5].

Neurodegenerative disease is broadly defined as the progressive atrophy of neurons and neural tissues. Loss of functional neurons may lead to impairments in cognition and/or movement. Since each neurodegenerative disease preferentially affects a defined population of neurons, unique clinical profiles are associated with the different conditions [6]. Although shared mechanisms may contribute to neuronal loss in multiple diseases, the distinct pathological profiles are caused by specific genetic mutations and/or toxic aggregation of particular proteins. Some well-known hallmarks of neurodegenerative diseases include mutant hungtingtin (mHTT) aggregates in Huntington's disease (HD) [7], $\alpha$-synuclein-associated Lewy bodies in Parkinson's disease (PD) [8], Amyloid- $\beta$ aggregation and hyperphosphorylated Tau in Alzheimer's disease (AD) [9], and TDP43 proteinopathies in frontotemporal lobe dementia (FTLD) [10] and amyotrophic lateral sclerosis (ALS) [11]. Thus, clearance of neurotoxic aggregates is a major focus of phenotypic assays for drug development, including those that measure autophagy-lysosomal network function and ubiquitinproteasome-mediated protein degradation. Other assays measure endpoints related to cellular viability or neuronal death, such as caspase-dependent apoptosis [12], oxidative stress-induced mitochondrial dysfunction [13], and neurotrophic factor expression [14]. Current platforms for modeling neurodegeneration include a combination of patient-derived induced pluripotent stem cells (iPSCs), cellular models and animal models, which all recapitulate at least some disease-relevant phenotypes
[6]. A number of promising therapeutic leads have been identified using these platforms, including antibodies, small molecules and other chemically modified drugs $[11,15]$. However, a lack of approved effective treatments is still the primary clinical challenge for managing neurodegenerative diseases.

There is a growing list of ncRNAs that functionally associate with neural differentiation and function [16, 17], and it is thought that many ncRNAs and their related RNA networks may affect neurodegeneration [18]. As pathological mutations are linked to over-abundance/aggregation of certain proteins, ncRNAs have been studied in relation to distinct proteostatic events and pathogenesis in diseases, such as HD [7], PD [12] and FTLD and ALS [19]. ncRNAs have also been found to regulate shared signaling pathways, such as apoptosis, mitochondrial dysfunction and neurotrophic factor depletion in neurons and microglia [20-22]. Despite many exciting advances in ncRNA biology, the relationship between ncRNA and disease pathogenesis remains elusive. In this review, we survey the emerging roles of ncRNAs in adult-onset-associated neurodegenerative diseases, including $\mathrm{HD}, \mathrm{PD}, \mathrm{AD}, \mathrm{FTLD}$ and ALS. We also summarize the current knowledge of how ncRNAs may affect disease-relevant mechanisms, such as HTT aggregation in HD (Fig. 1), $\alpha$-synuclein aggregation in PD (Fig. 2), amyloid- $\beta$ secretion and pTau accumulation in AD (Figs. 3 and 4).

\section{ncRNAs in HD pathogenesis}

$\mathrm{HD}$ is a monogenic progressive neurodegenerative disease caused by expansion of a CAG repeat in the hungtingtin (HTT) gene. The expanded CAG repeat encodes a toxic polyglutamine tract that preferentially kills GABAergic projection neurons. Striatal medium spiny neurons (MSNs) are the major susceptible cell type in HD, and an extensive body of literature has shown recapitulation of HD phenotypes in mouse and cellular models after induction of HTT aggregation, RESTdependent BDNF depletion or mitochondrial dysfunction [6]. Many RNA species have been implicated in the etiology of HD as well (Table 1). Among these implicated RNAs, miRNA-mRNA networks are the most well-studied and clearly regulate phenotypes in HD models (Fig. 1a). In addition, several lncRNAs have been shown to regulate HD-related gene transcription via chromatin recruitment of repressors (Fig. 1b).

\section{nCRNAs in the regulation of HTT expression/aggregation}

mHTT aggregation is the primary phenotype of HD, and ncRNAs are known to regulate HTT expression and aggregation. Several ncRNAs directly regulate HTT transcripts to affect aggregation. For example, HTTAS- $v 1$, the antisense RNA derived from $H T T$, regulates mHTT 

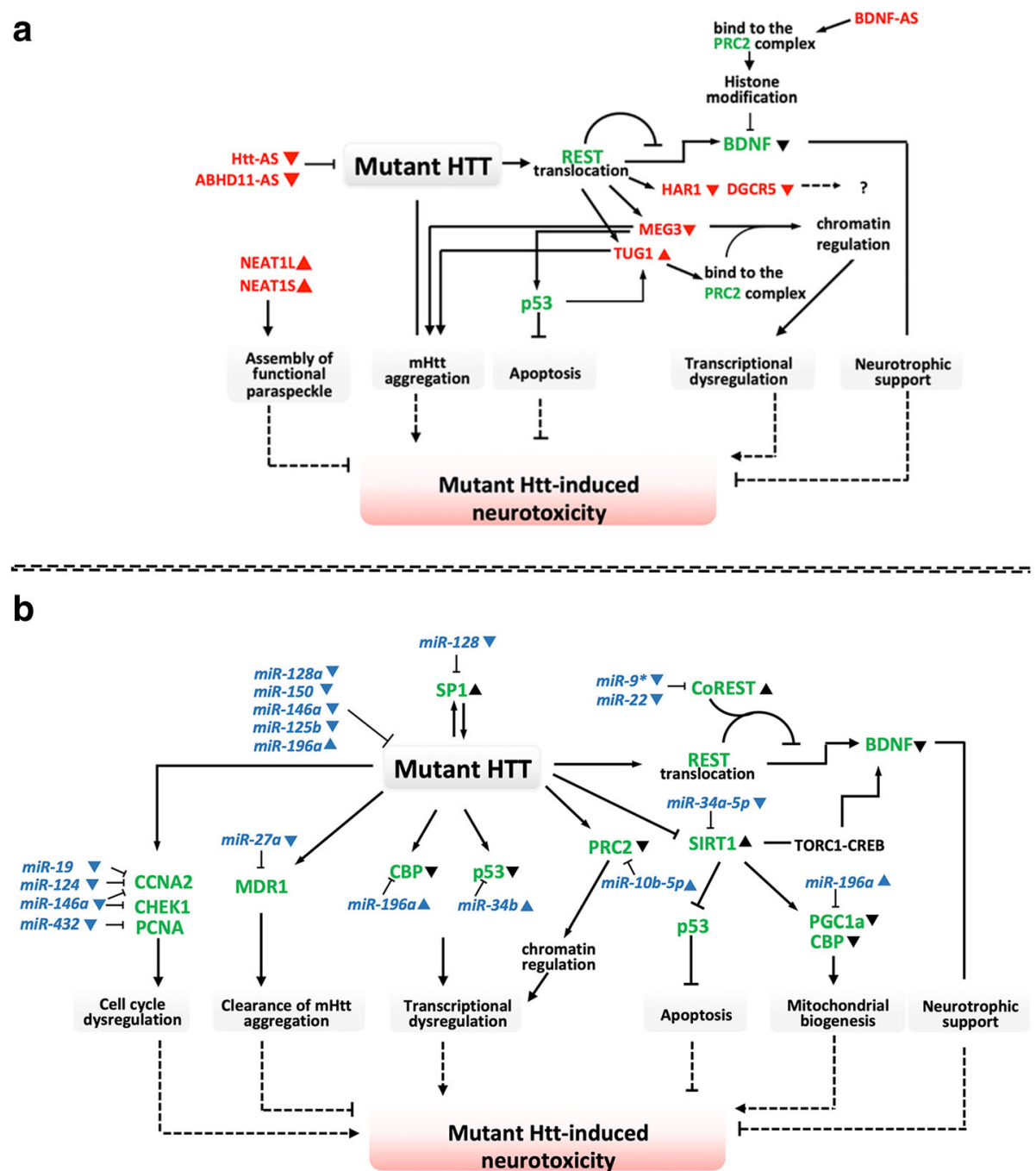

Fig. 1 Cellular functions of ncRNAs involved in HD pathogenesis. (a) LncRNAs regulate mutant Htt induced neurotoxicity. (b) Networks of mutant $\mathrm{Htt}$, microRNAs and mRNAs regulate neurotoxicity in HD. LncRNAs are shown in red, mRNA are shown in green and microRNAs are shown in blue

expression via dicer-dependent pathway and reduces the endogenous mHTT transcript level through a RISCdependent microRNA-like mechanism. Because downregulated HTTAS- 1 can be observed in HD brain sections, this NAT is thought to play a protective role in HD [7]. Certain microRNAs, including miR-214, miR150, miR-146a and miR-125b, directly target the 3'UTR of both HTT and $m H T T$, which reduces HTT expression in human and mouse models [40, 49]. These microRNAs protect neurons, and miR-146a, miR-150 and miR-125b are downregulated in the striatum of the commonly used HD model, R6/2 mice [41]. Since miR-125b and miR150 target $\mathrm{p} 53$, which regulates expression of the p65 subunit of NFKB (RelA/NFkB) and miR-146a, the regulatory mechanisms of miRNA-146a-, 125b- and 150dependent HTT expression have been further linked to apoptosis in HD [41]. In transgenic HD monkeys, HTT is directly regulated by miR-128a, which targets the 3' UTR of HTT. Additionally, miR-128a targets transcription factors, Huntingtin Interaction Protein 1 (HIP1) and SP1, which promote HTT transcription. Thus, downregulation of miR-128a contributes to HTT related phenotypes by both direct and indirect mechanisms [44]. HTT transcription is also regulated by ncRNAs in HD models. For example, ABHD11-AS (MGI Symbol: Abhd11os), the antisense of Abhd11, reduces mHTTmediated toxicity by altering mHTT transcription and was shown to contribute to striatal vulnerability in HD mouse models [32]. Moreover, ncRNAs are involved in defective HTT protein degradation in HD models. Clearance of $\mathrm{mHTT}$ by Multidrug resistance protein 1 (MDR1) is relevant to HTT aggression, and miR-27a is 


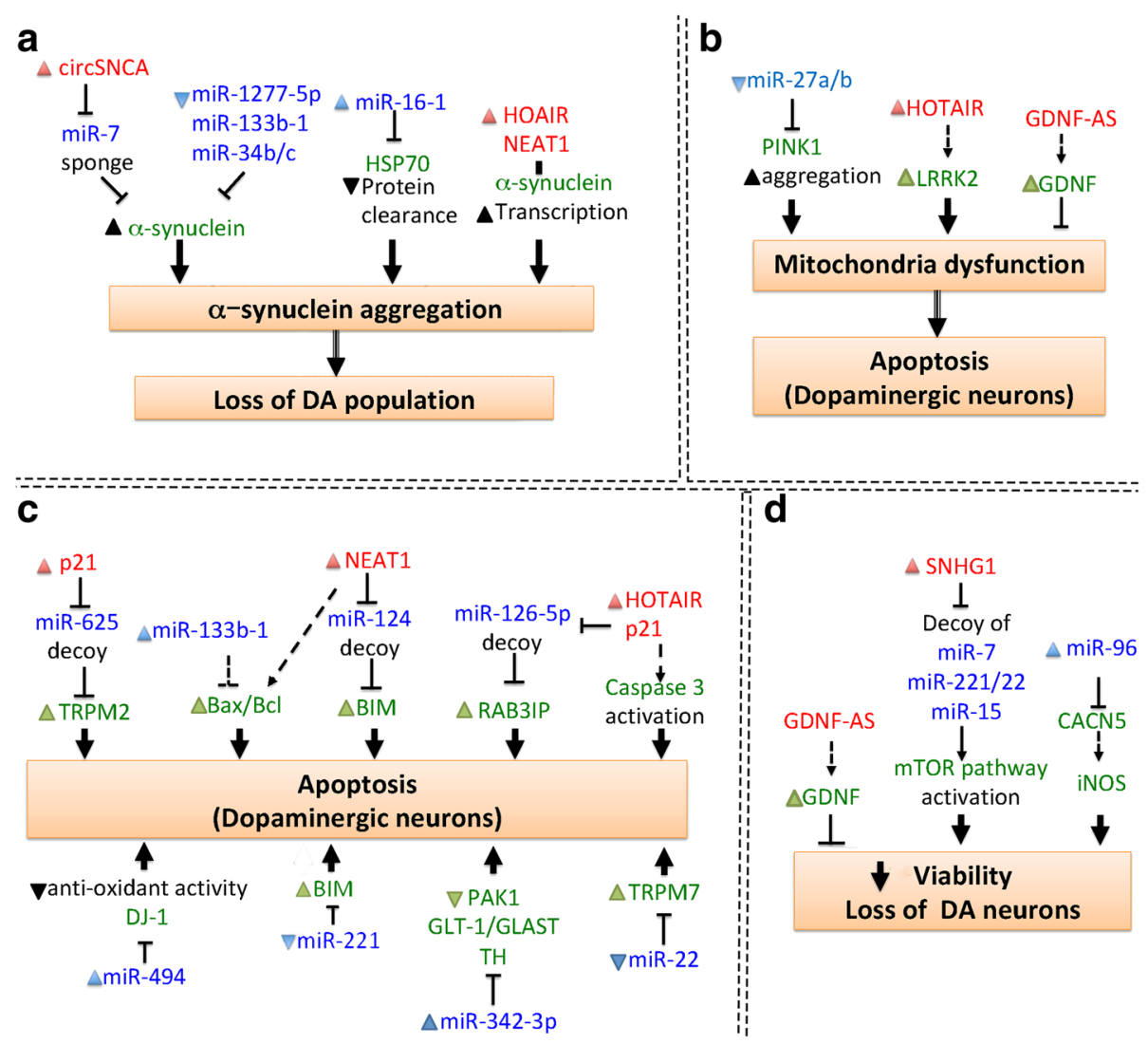

Fig. 2 Cellular functions of ncRNAs involved in PD pathogenesis. (a) ncRNAs affect a-synuclein formation, which is linked to loss of dopaminergic (DA) neurons. (b) ncRNAs regulate apoptotic pathways leading to DA neuron degeneration. (c) ncRNAs regulate mitochondrial dysfunction. (d) ncRNAs regulates DA neuron viability

involved in MDR1 expression. The downregulation of MDR1, possibly by miR-27a, in HD increases HTT expression [37]. mHTT expression is also decreased by miR-196a through alterations in the ubiquitinproteasome system, gliosis, cAMP response elementbinding protein and several neuronal regulatory pathways in vivo. Since miR-196a confers protective effects in $\mathrm{HD}$, its potential as a therapeutic target has been suggested [48].

\section{nCRNAs in the regulation of REST activity and BDNF expression}

Expression of Brain-derived neurotropic factor (BDNF) is downregulated in HD patients, and BDNF supplementation reduces mHTT-induced neurotoxicity in HD models. The BDNF antisense RNA (BDNF-AS) reduces BDNF expression via transcriptional repression, which involves polycomb repressive complex 2 (PRC2) recruitment to the BDNF locus and induction of histone H3K27 trimethylation. Thus, BDNF-AS is thought to play an important role in the development of HD [25, $33,34]$. In the prefrontal cortex of HD models, miR10b-5p reduces BDNF expression through a direct interaction. Upregulation of miR-10b-5p is correlated to BDNF transcription with aberrant PRC2 regulation on the BDNF locus occurring by an unknown mechanism [36, 50]. Sirtuin 1 (SIRT1) is downregulated by miR-34a binding to the 3' UTR of SIRT1 mRNA. Thus, the downregulation of miR-34a may provide a mechanistic link between BDNF expression and mitochondrial biogenesis [38].

In HD, BDNF depletion is linked to Repressor element 1-silencing transcription factor (REST)-dependent transcription regulation. REST is neuron-specific repressor of transcription, which is involved in demethylation of histone H3 lysine 4 (H3K4). The recruitment of a repression complex is an essential step in REST-mediated repression, and cofactors include SANT-domaincontaining CoREST and BHC110 (also known as LSD1) demethylase, among others [51]. Normally, HTT prevents REST-mediated transcriptional repression by acting in a cytoplasmic complex with Huntingtin-associated protein 1 (HAP1). This function is lost in mHTT, allowing REST to assemble its repressor complex in the nucleus [52]. Thus, mHTT permits REST translocation from cytoplasm to nucleus, which then leads to BDNF 


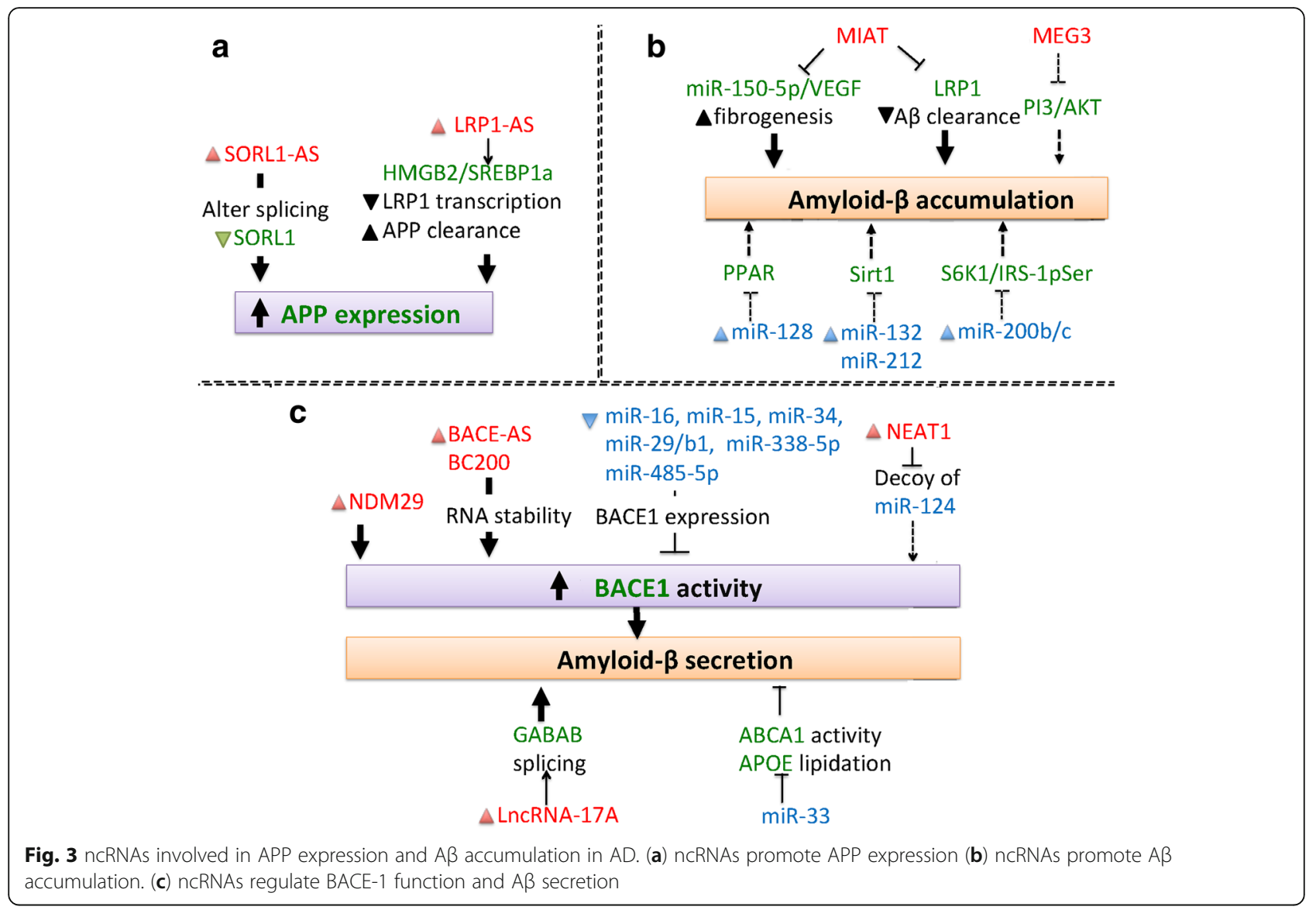

transcription repression and depletion [53]. Human accelerated region 1 (HAR1) is a direct target of REST, and a reduction in HAR1F/R transcript levels leads to repression of several important neuronal genes with unknown functions in human HD striatum [23]. DiGeorge syndrome critical region gene 5 (DGCR5) is a lncRNA that is regulated by REST, and the downregulation of DGCR5 in HD brain suggests it may play an important transcriptional regulatory role in HD development [24].
Maternally expressed 3 (MEG3) is also regulated by REST, and it associates with the PRC2 complex in chromatin. Downregulation of MEG3 was reported in human HD brain and may modulate mHTT aggregation [25]. miR-9 and miR-22 were found to target several gene transcripts, including HDAC4, REST corepressor 1 (coREST) and Rgs2; these miRNAs were therefore linked to HD by repression of coREST expression, which normally promotes REST-mediated BDNF depletion [26]. As such,

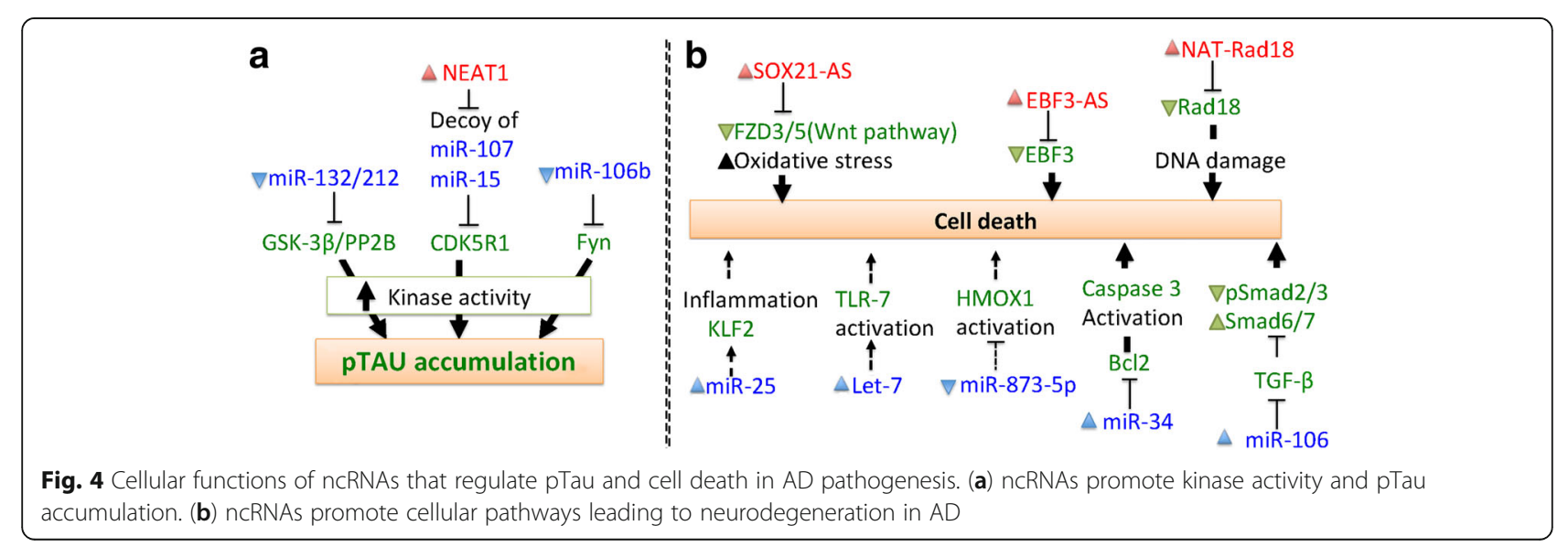


Table 1 ncRNAs and related processes in Huntington's disease

\begin{tabular}{|c|c|c|c|c|c|}
\hline & Name & $\begin{array}{l}\text { up/down } \\
\text { regulation }\end{array}$ & Description & model & Ref \\
\hline \multirow[t]{10}{*}{ IncRNA } & HARIF, HARIR & down & $\begin{array}{l}\text { HARIF and HARIR are direct targets of REST. Leading to thr } \\
\text { repression of several important neuronal genes. }\end{array}$ & human HD brain_striatum & [23] \\
\hline & DGCR5 & down & $\begin{array}{l}\text { DGCR5 is a REST target IncRNA, which plays an important } \\
\text { transcriptional regulatory role in HD }\end{array}$ & human HD brain & [24] \\
\hline & MEG3 & down & $\begin{array}{l}\text { MEG3 is a direct target of REST and found in the chromatin } \\
\text { compartment of the cell in association with PRC2 complex }\end{array}$ & human HD brain & {$[25,26]$} \\
\hline & MEG3, NEAT1 & up & $\begin{array}{l}\text { Loss of function of Meg3 and Neat1 modulated } \mathrm{mHtt} \\
\text { aggregates and downregulation of the Tp53 expression }\end{array}$ & $\mathrm{R} 6 / 2$ mouse cortex & [27] \\
\hline & NEAT1-L, NEAT1-S & up & $\begin{array}{l}\text { NEAT1 provides neuroprotection against } \mathrm{mHtt} \text {-induced } \\
\text { cytotoxicity (NEAT1-L) and oxidative stress-induced injury } \\
\text { (NEAT1-S). }\end{array}$ & $\mathrm{R} 6 / 2$ mouse brain & {$[27-29]$} \\
\hline & TUG1 & up & $\begin{array}{l}\text { TUG1 is a direct downstream target of p53 and could } \\
\text { modulate mHTT-induced cytotoxicity by p53 activation. } \\
\text { TUG1 could be able to binding to the PRC2 epigenetic } \\
\text { regulatory complex. }\end{array}$ & human HD brain & {$[30]$} \\
\hline & TUNA & down & $\begin{array}{l}\text { TUNA expression was associated with pathological } \\
\text { disease severity, decreasing significantly as the disease } \\
\text { grade increased. }\end{array}$ & human HD brain_caudate nucleus & [31] \\
\hline & LINC00341 & up & unknown & human HD brain & [25] \\
\hline & RPS2OP22 & up & $\begin{array}{l}\text { RPS20P22 regulates RPS20, which decreases will lead to } \\
\text { accumulation of p53. }\end{array}$ & human HD brain & [25] \\
\hline & LINC00342 & down & unknown & human HD brain & [25] \\
\hline \multirow[t]{3}{*}{ NATS } & Abhd11-os & down & $\begin{array}{l}\text { Abhd11-os (called Abhd11-AS1 in human) attenuate the } \\
\text { mHtt-induced tocixity and contribute to striatal } \\
\text { vulnerability in HD. }\end{array}$ & R6/2 mouse model & {$[32]$} \\
\hline & HTTAS_V1 & down & $\begin{array}{l}\text { HttAS-v1 reduces endogenous mHtt tanscript level } \\
\text { through RISC-dependent miR-like mechanism }\end{array}$ & human HD brain_frontal cortex & [7] \\
\hline & $B D N F-A S$ & & $\begin{array}{l}\text { BDNF-AS was associated with the recruitment of polycomb } \\
\text { repressive complex } 2 \text { (PRC2), which locally induces the } \\
\text { trimethylation of histone H3K27 within the locus and in } \\
\text { that way plays an important role in the development of HD. }\end{array}$ & & {$[25,33,34]$} \\
\hline others & sCAGs & up & $\begin{array}{l}\text { sCAG significantly decreased HTT-mediated neuronal viability } \\
\text { in an Ago2-dependent mechanism. }\end{array}$ & $\mathrm{R} 6 / 2$ mouse striatum; human $\mathrm{HD}$ brain & [35] \\
\hline \multirow[t]{11}{*}{ miRNAs } & miR-9* & down & $\begin{array}{l}\text { miR-9* targets the components of the REST repressor } \\
\text { complex, CoREST and modulating the neurotrophic genes } \\
\text { expression. }\end{array}$ & HD patient & [26] \\
\hline & miR-10b-5p & up & $\begin{array}{l}\text { miR-10b-5p targets BDNF and correlated to aberrant } \\
\text { polycomb repressive complex2 (PRC2) regulation. }\end{array}$ & HD brain_profrontal cortices & {$[36]$} \\
\hline & $\operatorname{miR}-22$ & down & $\begin{array}{l}\text { miR-22 was found to target HDAC4, Rcor } 1 \text { (COREST) and } \\
\text { Rgs2 mRNA and achieve neuroprotection and inhibit } \\
\text { neurodegeneration. }\end{array}$ & HD brain & [26] \\
\hline & miR-27a & down & $\begin{array}{l}\text { miR-27a increases MDR-1 expression; miR-27a can decrease } \\
\text { the mHtt aggregates possibly through MDR-1 modulation. }\end{array}$ & R6/2 mice & [37] \\
\hline & $\operatorname{miR}-34 a-5 p$ & down & $\begin{array}{l}\text { miR-34a downregulated SIRT1 through binding the } 3^{\prime} \text { UTR } \\
\text { of sirt1 mRNA. }\end{array}$ & R6/2 mice & [38] \\
\hline & miR-34b & up & $\begin{array}{l}\text { miR-34b is a P53-regulated miRNA and the levels may } \\
\text { influence mHTT cytoplasmic distribution and toxicity }\end{array}$ & HD patient, plasma & [39] \\
\hline & $\begin{array}{l}\text { miR-214, miR-125b, } \\
\text { miR-146a, miR-150 }\end{array}$ & down & $\begin{array}{l}\text { miR-214, miR-150, miR-146a and miR-125b target both } \\
\text { huamn HTT and mouse Htt. }\end{array}$ & STHdh(Q111)/Hdh(Q111) cells & {$[40]$} \\
\hline & $\begin{array}{l}\text { miR-125b, miR- } \\
\text { 146a, miR-150 }\end{array}$ & down & $\begin{array}{l}\text { miR-146a, miR-150 and miR-125b are decreased in striatum } \\
\text { of R6/2 mice. miR-125b and miR-150 target p53, which in } \\
\text { turn regulates RelA/NFkB and miR-146a expressions }\end{array}$ & STHdhQ111/HdhQ111 cells & [41] \\
\hline & miR-124 & down & $\begin{array}{l}\text { Decreased miR-124 expression could increase CCNA2 and } \\
\text { is involved in deregulation of cell cycle }\end{array}$ & STHdhQ111/HdhQ111 cells & {$[42]$} \\
\hline & miR-124a & down & $\begin{array}{l}\text { The neuronal-specific miR-124 is dysregulated in HD tissues, } \\
\text { probably as a result of increased repression by REST. }\end{array}$ & $\mathrm{R} 6 / 2$ mouse brain & [43] \\
\hline & miR-128a & down & miR-128a targets the $3^{\prime}$ UTR of HTT, Huntingtin Interaction & Transgenic HD monkeys & [44] \\
\hline
\end{tabular}


Table 1 ncRNAs and related processes in Huntington's disease (Continued)

\begin{tabular}{|c|c|c|c|c|}
\hline Name & $\begin{array}{l}\text { up/down } \\
\text { regulation }\end{array}$ & Description & model & Ref \\
\hline & & Protein 1 (HIP1) and SP1. & & \\
\hline miR132 & down & $\begin{array}{l}\text { The level of miR-132 associated with Ago2. miR-132 } \\
\text { supplementation produced symptomatic improvement } \\
\text { of motor function and lifespan. }\end{array}$ & R6/2 mice & [45] \\
\hline miR-212/miR-132 & down & $\begin{array}{l}\text { miR-212/miR-132 clusters are significantly associated with } \\
\text { CAG length and implicated in neuronal survival and shows } \\
\text { strongest down-regulation in the striatum. }\end{array}$ & HD transgenic mice & [35] \\
\hline miR-196a & up & $\begin{array}{l}\text { miR-196a might improve mitochondrial function by the } \\
\text { upregulation of CBP and PGC-1a to promote oxidation } \\
\text { phosphorylation and reduce oxidative stress, which was } \\
\text { consistent with the amelioration of cytotoxicity by miR-196a. }\end{array}$ & HD brain, striatum & [46] \\
\hline miR-196a & up & $\begin{array}{l}\text { The higher expression of RAN binding protein } 10 \text { (RANBP10) } \\
\text { in the brains of HD transgenic mice and exacerbates } \\
\text { neuronal morphology and intracellular transport. } \\
\text { miR-196a suppress the expression of RANBP10 through } \\
\text { binding to its } 3^{\prime} U T R \text {. }\end{array}$ & HD transgenic mice brain & [47] \\
\hline miR-196a & up & $\begin{array}{l}\text { miR-196a decreased } \mathrm{mHTT} \text { expression and pathological } \\
\text { aggregates through alteration of several neuronal regulatory } \\
\text { pathways including ubiquitin-proteasome systems, gliosis } \\
\text { and cAMP response element-binding protein pathway. }\end{array}$ & HD-iPSC derived neurons & [48] \\
\hline $\begin{array}{l}\text { miR-19, miR-146a, } \\
\text { miR-432 }\end{array}$ & down & $\begin{array}{l}\text { The increase in the expressions of PCNA, CHEK1 and CCNA2 } \\
\text { was found to be the result of decreased expressions of } \\
\text { miR- } 432 \text {, miR-146a, and (miR-19a and miR-146a) respectively. } \\
\text { Exogenous expressions of these miR- } 432 \text { and miR-146a in } \\
\text { HD cells rescued the abnormalities in cell cycle and apoptosis. }\end{array}$ & STHdh(Q111)/Hdh(Q111) cells & [43] \\
\hline
\end{tabular}

miR-22 is thought to be neuroprotective and inhibits neuronal loss in HD brain $[54,55]$. The neuron-specific miR-124 is downregulated in HD mouse models, and REST was suggested to be a primary mediator of this effect [42]. Because miR-124 is associated with the cell cycle, REST appears to be involved in multiple mechanisms of HD pathogenesis [42].

\section{ncRNAs in the regulation of HD-associated apoptosis}

An expanded CAG repeat in HTT exon 1 is the cause of $\mathrm{HD}$, and decreasing the length of expanded repeats has been shown to improve neuronal viability. Exogenous expression of 21-nucleotide small-CAG repeated RNA ( $s C A G)$ regulates cell viability, similar to small RNA extracted from HD brain. This sCAG treatment activates an Ago2-dependent mechanism by targeting CAG regions of the mHTT transcript, significantly decreasing mHTT-mediated neuronal death [35]. Cytotoxicity of mHTT can also be modulated by Taurine Upregulated Gene 1 (TUG1) via p53. Since TUG1 also binds to the PRC2 epigenetic regulatory complex of genes, TUG1 upregulation may be involved in multiple molecular pathways in the human HD brain [30]. Furthermore, both MEG3 and NEAT1 are upregulated in HD mouse R6/2 cortex, and reducing MEG3 and NEAT1 expression modulates mHTT aggregates and TP53 expression through unknown mechanisms [27-29]. RPS20P22 regulates RPS20 expression, and the decrease of RPS20P22 leads to accumulation of p53 in HD brain [25]. In addition, apoptosis of GABAegic neurons is regulated by several microRNAs in HD. For example, miR-34b regulates P53 expression, which may influence mHTTmediated apoptosis. Upregulation of miR-34b in HD patient brain and plasma samples suggests it may also play a role in HD [39]. mHTT was shown to reduce miR-432, miR-146a, miR-19a and miR-146a in a cellular system. These miRNAs directly target cell cycle genes, such as PCNA, CHEK1 and CCNA2. Notably, cell cycle dysregulation is linked to the decreased expression of CCNA2, and exogenous expression of miR-432 and miR-146a in HD cells rescues cell cycle abnormalities and apoptosis [43].

\section{ncRNAs in other mechanisms of HD pathogenesis}

In the striatum of $\mathrm{HD}$ brains, reduced mitochondrial function is evidenced by low oxidative phosphorylation and high oxidative stress. Interestingly, miR-196a upregulation modulates mitochondrial function by its effects on CBP and PGC-1 $\alpha$, and targeting miR-196a was reported to restore mitochondrial function in $\mathrm{HD}$ [46]. Furthermore, miR-196a also targets the 3'UTR of RAN binding protein 10 (RANBP10), an action which enhances neuronal morphogenesis and intracellular transport in an HD mouse model [47]. In another example, the level of miR-132 is associated with Ago2-dependent HTT clearance in animal models of HD, and supplementation with miR-132 improves motor function and lifespan in an HD mouse [45, 56]. Although the 
mechanism is still unknown, TUNA expression is negatively associated with pathological disease severity, i.e., decreased TUNA is associated with increased disease grade in HD patients [31]. Moreover, in HD brains, the expression levels of LINC00341 and LINC00342 are significantly different in comparison with control subjects [25].

Taken together, mounting evidence shows that ncRNAs play many important roles in the development of HD, with much evidence coming from HD models (Table 1). Further understanding the functional roles of dysregulated ncRNAs in HD is expected help to unravel disease pathogenesis and identify potential therapeutic targets.

\section{ncRNAs in PD pathogenesis}

PD is an adult-onset neurodegenerative disorder that affects about $1 \%$ of people over 60 years of age. In this disease, a motor deficit is caused by selective loss of A9type dopaminergic neurons that project from the substantia nigra in the midbrain to the dorsal striatum. Intra-neuronal aggregation of $\alpha$-synuclein in Lewy bodies is a pathological hallmark of PD [8]. Approximately $10 \%$ of PD cases are inherited as genetic mutations of SNCA ( $\alpha$-synuclein), PARK2 (Parkin), PINK1 (PTEN-induced kinase 1), PARK7 (protein deglycase DJ-1), LRRK2 (leucine-rich repeat kinase) or ATP13A2 (ATPase type 13A). Most PD-causing mutations are in genes that regulate mitochondrial function and oxidative stress, and similarly, sporadic PD may be caused by certain environmental factors that disrupt mitochondrial function, such as pesticides and heavy metals. Thus, PD is often modeled with MPTP/MPP+ (1-methyl-4-phenyl1, 2, 3, 6-tetrahydropyridine) or 6-OHDA (6-hydroxydopamine), which induce mitochondrial dysfunction and oxidative stress in dopaminergic projection neurons [57]. ncRNAs have been reported to disrupt mitochondrial function via effects on gene expression and $\alpha$-synuclein aggregation (Table 2 and Fig. 2).

\section{nCRNAs in the regulation of a-synuclein expression and Lewy body formation}

$\alpha$-Synuclein upregulation is a crucial event that promotes its aggregation in Lewy bodies, and several ncRNAs have been found to regulate $\alpha$-synuclein expression and aggregation in PD (Fig. 2a). The IncRNA, NEAT1, promotes transcription of $\alpha$-synuclein, and it also enhances the $\mathrm{Bax} / \mathrm{Bcl}$ ratio and caspase 3 activity in PD; thus NEAT1 appears to participate in $\alpha$-synucleinassociated apoptosis [60]. Several downregulated microRNAs in PD patient tissues are linked to $\alpha$-synuclein upregulation and disease phenotypes. The downregulation of miR-34b/c prevents its targeting of the 3'UTR of $\alpha$ synuclein, leading to $\alpha$-synuclein upregulation.
Moreover, it has been proposed that single nucleotide polymorphisms (SNPs) in $\alpha$-synuclein reduce the binding capacity of miR-34b/c to promote $\alpha$-synucleinrelated PD pathogenesis [78]. Heat shock protein (HSP) 70 participates in the clearance of $\alpha$-synuclein aggregation, and miR-16-1-mediated HSP70 downregulation has been linked to increased $\alpha$-synuclein aggregation [74]. Another microRNA, miR-133b, also decreases $\alpha$ synuclein expression, the $\mathrm{Bax} / \mathrm{Bcl}$ ratio and pAkt activation to promote neuronal survival [20]. It was further reported that miR-133b targets RhoA to disinhibit axonal outgrowth. Notably, whole genome sequencing of PD patients failed to identify mutations/polymorphisms in miR-133b that are related to PD risk [72]. Thus, treatment with exogenous agents to increase miR-133b represents a potential therapeutic strategy for PD.

ncRNA networks have also been implicated in PD pathogenesis. For example, miR-1277-5p directly targets $\alpha$-synuclein (SCNA), reducing its expression. LncRNA$p 21$ is a decoy for miR-1277-5p and prevents the targeting of SCNA mRNA. Interestingly, the p21/miR-1277$5 \mathrm{p} / \alpha$-synuclein RNA network is required for apoptosis in models of MPP +-induced PD [64]. Furthermore, it was reported that miR-7 represses $\alpha$-synuclein protein expression by binding the 3'UTR of SCNA, an action that protects cell against oxidative stress [12]. The circRNA, circSNCA, is derived from SNCA mRNA CDS and serves as a miR-7 sponge. The upregulation of circSNCA therefore promotes $\alpha$-synuclein expression and pre-apoptotic gene expression (CASP3, BAX, PTEN and P53) in PD models. Thus, the circSNCA/miR-1277-5p/ $\alpha$ synuclein network positively regulates $\alpha$-synuclein expression. In line with this notion, downregulating circSNCA expression rescues cell death after pramipexole (PPX) treatment [12].

\section{ncRNAs in the regulation of PD-associated mitochondrial dysfunction}

Mitochondria dysfunction is a major cause of Parkinsonism and degeneration of dopaminergic neurons [81]. ncRNAs have also been found to regulate mitochondrial dysfunction, which leads to a loss of dopaminergic neurons (Fig. 2b). Dysregulation and aggregation of PTENinduced kinase 1 (PINK1), a mitochondrial kinase, has been implicated in PD pathology. When animals are treated with MPTP, the molecule is selectively taken up by dopaminergic neurons, inducing their degeneration via impaired mitochondrial function. NEAT1 upregulation is positively correlated with MPTP concentration, and promotes PINK1 protein stability. NEAT1 also promotes autophagy, as evidenced by an increased LC3-II/ LC3-I level in MPTP-treated mice [62]. Autophagy is an essential pathway of degrading cytoplasmic protein aggregates and defective organelles via targeting to 
Table 2 ncRNAs and related processes in Parkinson's disease

\begin{tabular}{|c|c|c|c|c|c|c|}
\hline & Name & $\begin{array}{l}\text { up/down } \\
\text { regulation }\end{array}$ & Stimulation & Description & Model & Ref \\
\hline \multirow[t]{13}{*}{ IncRNAs } & HOTAIR & up & MPTP & $\begin{array}{l}\text { correlated with LRRK2 upregulation and activating caspase } 3 \\
\text { dependent apoptosis }\end{array}$ & mouse model & {$[58]$} \\
\hline & HOTAIR & up & MPTP & $\begin{array}{l}\text { blocking miR-126-5p/RAB3IP interaction and promoting DA neurona } \\
\text { death }\end{array}$ & mouse model & [59] \\
\hline & NEAT1 & up & MPTP & $\begin{array}{l}\text { Positively correlated with treated MPTP concentration. NEAT1 } \\
\text { upregulation promotes Bax/BCI ratio, caspase } 3 \text { activity and a- } \\
\text { synuclein expression. NEAT1 knokdown promotes cell viability and } \\
\text { supresses apotosis. }\end{array}$ & mice, cell line & [60] \\
\hline & NEAT1 & up & MPTP & $\begin{array}{l}\text { NEAT1 correlated with neuroinflammation after MPP+ treatment (IL- } \\
1 \text { b, IL-6 and TNF-a upregulation). NEAT1 serves as miR-124 decoy and } \\
\text { promotes cell death and apoptosis. }\end{array}$ & mice, cell line & [61] \\
\hline & NEAT1 & up & MPTP & $\begin{array}{l}\text { NEAT1 promotes PINK1 protein stability via preventing degredation. } \\
\text { NEAT1 positively correlated to LC3-II/LC3-I level and promotes } \\
\text { autophogy. }\end{array}$ & mice, cell line & {$[62]$} \\
\hline & NORAD & down & MPP+ & $\begin{array}{l}\text { NORAD protects cell against MPP+ induced cytotixity inclduing } \\
\text { caspase } 3 / 7, \text { ROS and LDH activity with unknown mechanism. }\end{array}$ & cell line & [12] \\
\hline & $p 21$ & up & MPTP & $\begin{array}{l}\text { p21 positvely regulates TRPM2 expression by targeting miR-625. p21 } \\
\text { serves as a miR-625 decoy and inhibits TRPM2 function in causing } \\
\text { neuronal injury. }\end{array}$ & cell line & [63] \\
\hline & $p 21$ & up & MPTP & $\begin{array}{l}\text { p21 is miR-1277-5p decoy and prevents miR-1277-5p directly target- } \\
\text { ing a-synuclein expression. P21/miR-1277-5p/a-synuclein axis leads to } \\
\text { apoptosis in MPP+ induced PD models. }\end{array}$ & mouse & [64] \\
\hline & SNHG1 & up & MPTP & $\begin{array}{l}\text { SNHG-1 is a miRNA sponge of miR-221/222 and prevents p27 target- } \\
\text { ing and activation of mTOR pathway. Downregulation of SNHG1 at- } \\
\text { tenuated MPP+ induced decreases in LC3-II (an autophagic marker) } \\
\text { levels and cytotoxicity through the miR-221/222/p27/mTOR pathway. }\end{array}$ & cell line & [65] \\
\hline & SNHG1 & down & & miR-15 decoy and inhibit miR-15 function & cell line & [66] \\
\hline & SNHGI & up & LPS & $\begin{array}{l}\text { Upregulation of SNHG1 promotes neuroinflammation in BV2 microglia } \\
\text { of PD models. SNHG-1 functioned as a competing endogenous RNA } \\
\text { for miR-7 to regulate NLRP3 expression leading to the activation of } \\
\text { NLRP3 inflammasome. }\end{array}$ & mice, cell line & [67] \\
\hline & $\begin{array}{l}\text { U1 splicesomeal } \\
\text { IncRNA, RP11- } \\
462 \mathrm{G} 22.1\end{array}$ & up & & $\begin{array}{l}\text { Upregulated in patiensts' leukocyte, amygdala and substantia-nigra. } \\
\text { Computational prediction shows miRNA decoy, and exhibit a more } \\
\text { complex secondary stem-loop structure. Potentially as decoy of } 21 \\
\text { different miRNAs (potential ceRNA). }\end{array}$ & $\begin{array}{l}\text { PD patient } \\
\text { tissue }\end{array}$ & [68] \\
\hline & $\begin{array}{l}\text { tRNA-derived } \\
\text { fragment }\end{array}$ & & & $\begin{array}{l}\text { A list of tRNA-derived fragment are consistently founded in pateits' } \\
\text { CSF, serum and cortex. The tRNA-derived fragment are the bio- } \\
\text { markers of PD. }\end{array}$ & $\begin{array}{l}\text { PD CSF, cortex, } \\
\text { serum }\end{array}$ & [69] \\
\hline \multirow[t]{2}{*}{ NATS } & UCHL1-AS & & MPTP & $\begin{array}{l}\text { UCHL 1-AS is an antisense to the mouse ubiquitin carboxy terminal } \\
\text { hydrolase } L 1 \text { and activates transcription of UCHL1. UCHL1 is under } \\
\text { the regulation of Nurr1 (a major transcription factor) in dopaminergic } \\
\text { differentiation, maintenance and related to cellular stress in the brain. }\end{array}$ & $\begin{array}{l}\text { mouse, PD } \\
\text { patient }\end{array}$ & [25] \\
\hline & GDNF-AS & & 6-OHDA & $\begin{array}{l}\text { GDNF-AS is coded for GDNF and enable to promote GDNF expression } \\
\text { by } 2 \text { fold. GDNF-AS delivery by Adeno-associated virus was able to } \\
\text { ameliorate motor deficits and neurodegeneration of DA neurons in a } \\
\text { PD mouse models lesioned by6-OHDA treatment. }\end{array}$ & mouse & [70] \\
\hline circRNAs & $\operatorname{circSNCA}$ & up & $\mathrm{MMP}+$ & $\begin{array}{l}\text { circSNCA serve as a miR-7 sponge and prevents miR-7 targeting SNCA } \\
\text { expression. Increased SNCA induce pro-apoptotic genes (CASP3, BAX, } \\
\text { PTEN and P53). Knockdown of circSNCA shows the anti-apoptotic } \\
\text { gene (BCL2) expression and prevents apoptosis. }\end{array}$ & cell line & [12] \\
\hline \multirow[t]{3}{*}{ miRNAs } & miR-126 & up & 6-OHDA & $\begin{array}{l}\text { miR-126 directly targets p85b, IRS-1, SPRED1 and impaires IGF-1/PI3K } \\
\text { AKT signaling. miR-126 leads to 6-OHDA induced neurotoxity. }\end{array}$ & cell line & [71] \\
\hline & miR-126-5p & down & & $\begin{array}{l}\text { miR-126-5p increase cell proliferation and reduce apotosis via } \\
\text { targeting RAB3IP }\end{array}$ & cell line & [59] \\
\hline & miR-133a/b & & & $\begin{array}{l}\text { miR-133 targeted PITX3 mutations/polymorphisms are not related to } \\
\text { PD risk. }\end{array}$ & $\begin{array}{l}\text { human genome } \\
\text { sequence }\end{array}$ & {$[72]$} \\
\hline
\end{tabular}


Table 2 ncRNAs and related processes in Parkinson's disease (Continued)

\begin{tabular}{|c|c|c|c|c|c|}
\hline Name & $\begin{array}{l}\text { up/down } \\
\text { regulation }\end{array}$ & Stimulation & Description & Model & Ref \\
\hline miR-133b & down & & $\begin{array}{l}\text { miR-133b targets RhoA (inhibitor of axonal growth) and indcue } \\
\text { axonal outgrowth. miR-133b inhibits a-synuclein expression, Bcl/bax } \\
\text { ratio and activates pAkt for neuronal survival. }\end{array}$ & cell line & $\overline{[72]}$ \\
\hline miR-153 & down & $\mathrm{MPP}+$ & $\begin{array}{l}\text { miR-153 reduces p38 activation and prevents neuro-inflammation in- } \\
\text { duced apoptosis }\end{array}$ & $\begin{array}{l}\text { mouse primary } \\
\text { cortical neuron }\end{array}$ & [73] \\
\hline miR-16-1 & up & & $\begin{array}{l}\text { miR-16-1 targets Hsp70 3'UTR and negatively regulate a-synuclein } \\
\text { aggregation }\end{array}$ & SH-SY5Y & [74] \\
\hline miR-183 & up & & $\begin{array}{l}\text { miR-183 promotes apotosis of substantia nigra neuron by inhibit the } \\
\text { expression of OSMR. }\end{array}$ & cell line & [75] \\
\hline miR-205 & down & & $\begin{array}{l}\text { mir-205 suppresses the expression of LRRK2 protein through a } \\
\text { conserved-binding site at the } 3 \text { '-UTR of LRRK2 gene and promotes } \\
\text { neurite outgrowth. }\end{array}$ & PD brain section & [76] \\
\hline miR-22 & down & 6-OHDA & $\begin{array}{l}\text { miR-22 overexpression downregulates the level of TRPM7, exhibited } \\
\text { neuroprotective and reversal effect on the 6-OHDA-induced PCL2 cell } \\
\text { growth and apotosis. }\end{array}$ & cell line & [77] \\
\hline miR-221 & down & MPP+ & $\begin{array}{l}\text { DJ-1 may increase miR-221 expression through the MAPK/ERK path- } \\
\text { way, leading the repression of apototic molecules BIM. }\end{array}$ & cell line & [70] \\
\hline miR-27a/b & down & CCCP & $\begin{array}{l}\text { miR-27a/b suppress PINK1 expression through targeting 3' UTR. } \\
\text { Donwregulated PINK1 by miR-27a/b prevents its aggregation upon } \\
\text { mitochondria damage and inhibits lysosomal degradation of dam- } \\
\text { aged mitochondria. }\end{array}$ & cell line & [21] \\
\hline miR-342-3p & up & MPTP & $\begin{array}{l}\text { miR-342-3p directly targets PAK1 ( } 21 \text {-activated kinase } 1 \text { ) in Wnt } \\
\text { signallg pathway. miR-342-3p also reduce expression of GLT-1, GLAST, } \\
\text { and leads to reduce TH expression and the related apoptosis. }\end{array}$ & mouse & {$[6]$} \\
\hline $\mathrm{miR}-34 \mathrm{~b} / \mathrm{c}$ & down & & $\begin{array}{l}\text { miR-34b/c targets a-synuclein } 3^{\prime} U T R \text { and reduces expression. In SNP } \\
\text { of a-synuclein in Parkinson's disease, failed miR-34b/c targeting } \\
\text { causes a-synuclein expression and the related PD pathogenesis. }\end{array}$ & cell line & [78] \\
\hline miR-494 & up & MPTP & $\begin{array}{l}\text { miR- } 494 \text { directly binds to } 3^{\prime}-U T R \text { of DJ- } 1 \text { transcript and inversely regu- } \\
\text { lates the expression of DJ-1 which compromise anti-oxidative de- } \\
\text { fence of cell. }\end{array}$ & mice & [79] \\
\hline miR-7 & down & & $\begin{array}{l}\text { miR-7 represses a-synuclein protein level through binding 3' UTR of } \\
\text { A4 component of amyloid precursor (SCNA; gene name of a- } \\
\text { synuclein) and protects cell against oxidative stress. }\end{array}$ & PD brain section & [12] \\
\hline miR-7/miR-153 & down & MPP+ & $\begin{array}{l}\text { Both miR-7 and miR-153 activate p70S6K/pS6RP/SAPK/NNK mediated } \\
\text { mTOR pathway. }\end{array}$ & $\begin{array}{l}\text { mouse primary } \\
\text { cortical neuron }\end{array}$ & [73] \\
\hline miR-96 & up & MPTP & $\begin{array}{l}\text { CACNG5 is the target gene of miR-96. CACNG5 and BCL2 inhibition } \\
\text { are linked to the activation of iNOS and apotosis. }\end{array}$ & mice & [80] \\
\hline
\end{tabular}

lysosomes. Imbalances of autophagy are linked to the retention of dysfunctional mitochondria in cells, which contributes to neurodegeneration in PD. As PINK1 is essential for the induction of mitochondrial autophagy, mutations in PINK1 have been linked to autophagy imbalances and PD [21, 62]. Several microRNAs that target PINK1 have been identified in PD models. For example, PINK1 can be reduced by direct targeting with miR-27a/b, which inhibits lysosomal degradation of damaged mitochondria [21].

Protein deglycase DJ-1 (parkin7) is essential for combatting oxidative stress in PD. Functionally, DJ-1 protects neurons from apoptosis by increasing miR-221 expression, leading to repression of proapoptotic BIM. Although the direct target of miR-221 is unknown in $\mathrm{PD}, \mathrm{DJ}-1$ potentially regulates miR-221 transcription via the MAPK/ERK signaling pathway [70]. In another example, the DJ-1 transcript is targeted by miR-494 and inversely regulates DJ-1 expression, compromising the antioxidant defenses of the cell [79].

Dysregulation of leucine-rich repeat kinase 2 (LRRK-2) is one of the most common PD-linked effects on kinases. In the MPTP-treated mouse model, lncRNA HOTAIR (Hox transcript antisense intergenic RNA) is upregulated, along with LRRK2 upregulation and induction of caspase 3-dependent apoptosis. Reducing HOTAIR can rescue dopaminergic neuron degeneration and reduce LRRK2 expression by some unknown mechanism [58]. miR-205 targets the 3'UTR of LRRK2 and suppresses its expression. MiR-205 downregulation is observed in brains of PD patients, including those with either sporadic disease or those with familial PD derived from the 
LKKR2(R1441G) mutation. Overexpression of miR-205 can reduce LRRK2 expression and promote neurite outgrowth in cell models [76].

\section{ncRNAs in the regulation of PD-associated apoptosis}

As the loss of dopaminergic neurons is responsible for symptoms in PD patients, signaling pathways that control cytotoxicity may be targetable to prevent neuronal loss (Fig. 2c and d). LncRNA activated by DNA damage $(N O R A D)$ is an exonic transcript from Chr20q11.23 that sequesters PUMILIO proteins to promote genome stability. In MPP + -treated cells, NORAD is downregulated, promoting cytotoxicity, caspase $3 / 7$ activation, ROS production and LDH release. Lentivirus-expressed NORAD protects cell against MPP+ cytotoxicity by unknown mechanisms [12]. Another category of ncRNAs, tRNA halves $(t R H s)$, are tRNA-derived fragments $(t R F \mathrm{~s})$ that have been implicated in cell stress and neurodegeneration in PD tissues [68]. Moreover, several microRNAs are known to regulate PD-associated apoptosis by directly repressing gene expression. miR-126 is involved in regulating neuronal toxicity and cell death processes. In 6-OHDA-treated PD cell models, miR-126 is upregulated and directly targets p85b, IRS-1, SPRED1 to suppress IGF-1/PI3K/AKT signaling. Along with other mechanisms, this action leads to neurotoxicity [71]. MiR-96 is upregulated in MPTP-treated PD mouse models, where it targets CACNG5. CACNG5 and $\mathrm{Bcl} 2$ inhibition are linked to the activation of iNOS and apoptosis [80]. In addition, upregulation of miR-342-3p can be detected in MPTP-treated mice. MiR-342-3p directly targets PAK1 (p21-activated kinase 1) in the Wnt signaling pathway and also reduces expression levels of Glutamate transporter subtype 1 (GLT-1) and L-glutamate/ L-aspartate transporter (GLAST). These actions impair neuronal viability and lead to apoptosis [6]. In 6-OHDAtreated cell lines, miR-22 is downregulated. Exogenous overexpression of miR-22 markedly downregulates TRPM7, inhibiting neurotoxicity and rescuing cell growth [77]. Downregulation of miR-126-5p has also been implicated in causing PD-like toxicity in cell lines. As miR-126-5p increases cell proliferation and reduces apoptosis by targeting RAB3IP, this microRNA can protect neurons from apoptosis [59]. In MPP +-treated cells, both miR-7 and miR-153 are downregulated. The p70S6K/pS6RP/SAPK/JNK axis of the mTOR pathway is inactivated by both miR-7 and miR-153 by unknown mechanisms [73]. Moreover, miR-183 upregulation promotes apoptosis of neurons in the substantia nigra and inhibits OSMR expression [75].

Recently, studies on the more complex RNA networks (i.e., lncRNA/microRNA/mRNA) have revealed further effects on apoptosis in PD. In MPP +-treated mice, HOTAIR promotes apoptosis and reduces cell viability.
Knockdown of HOTAIR protects from death of dopaminergic neurons by inhibiting caspase 3 activity. HOTAIR prevents microRNA-126-5p from targeting RAB3IP. As RAB3IP promotes autophagy and is involved in neuronal death in $\mathrm{PD}$, this action promotes apoptosis. The HOTAIR/miR-126-5p/RAB3IP axis is linked to PD progression and its disruption has been suggested as a therapeutic target for PD [59]. Small nucleolar RNA host gene 1 (SNHG1) is gradually upregulated in MPP +-treated cells and animal models. Knockdown of SNHG1 reduces LC3-II expression and MPP +-induced cell death. The microRNA-221/222 cluster is also associated with PD by virtue of its downregulation in blood samples of PD patients. MicroRNA-221/222 facilitates LC3-II formation and reduces MPP +-induced neurotoxicity. SHNG1 can serve as a miRNA sponge for miR-221/222 and prevents targeting of p29, a key regulator of mTOR phosphorylation and cell death [65]. LncRNA-p21 upregulation also promotes caspase 3 activation and increases Bcl family-initiated apoptosis. TRPM2, a nonselective $\mathrm{Ca}^{2+}$-permeable channel, is upregulated in the brain of PD patients [82]. It has been shown that miR-625 directly targets TRPM2 to prevent its expression. LncRNA- $p 21$ serves as a sponge for miR625 , and thus, it promotes TRPM2 expression. This $p 21 /$ miR-625/TRPM2 regulatory network has also been linked to PD pathogenesis [63].

\section{ncRNAs involved in other mechanisms of PD pathogenesis}

Glial cell-derived neurotrophic factor (GDNF) deficiency has been demonstrated in PD models, and exogenous GDNF promotes dopaminergic neuron survival. GDNF-AS is coded for by GDNF mRNA and promotes GDNF expression by 2-fold. GDNF-AS delivery by Adeno-associated virus (AAV) ameliorated motor deficits and neurodegeneration of dopaminergic neurons in a mice with unilateral 6OHDA lesions [70]. UCHL1-AS is an antisense RNA to ubiquitin carboxy terminal hydrolase L1 (UCHL1) that activates its translation. UCHL1 is under the regulation of Nurr1 (a major transcription factor) and functions in dopaminergic neuron differentiation and maintenance as well as cellular stress response in the brain. UCHL1 is mutated in a rare form of early-onset PD and loss of activity is responsible for disease. Overexpression of UCHL1-AS has been suggested as a method to promote translation of UCHL1 and prevent neurodegeneration [69].

LncRNA- $p 21$ promotes neuroinflammation by mechanisms including IL-1 $\beta$, IL-6 and TNF- $\alpha$ upregulation. In $\mathrm{MPP}+$-treated primary neurons, miR-153 is downregulated, which results in increased p38 activation and promotion of neuroinflammation-mediated apoptosis [73]. NEAT1 is also correlated with neuroinflammation after $\mathrm{MPP}+$ treatment, based on its upregulation of IL- $1 \beta$, IL- 6 
and TNF- $\alpha$. An RNA immunoprecipitation assay revealed that NEAT1 serves as a miR-124 sponge and promotes apoptosis in MPTP-treated cells [61]. In BV microglial cells, SHNG1 is upregulated during lipopolysaccharide-induced inflammation. Silencing SHNG1 expression promotes miRNA-7 targeting of nod-like receptor protein 3 (NLRP3) expression and leads to activation of NLRP3 neuroinflammation. Thus, the action of SHNG1 as a miRNA sponge for miRNA-7 promotes neuroinflammation in BV2 microglia [66].

In addition to the involvement of lncRNAs and microRNAs, tRNA-derived fragments ( $t R F \mathrm{~s})$ are consistently founded in the CSF, serum and cortex of PD patients. Thus, the profiles of tRFs can be potentially used as biomarkers of PD [68]. Transcriptome analyses of leukocytes and brain samples from PD patients have been used to identify several PD-associated lncRNAs. For example, U1 splicesomal lncRNAs and RP11-462G22.1 are upregulated in patient leukocytes, amygdala and substantia nigra. Computational predictions show these lncRNAs may function as protective miRNA decoys and prevents the functioning of their complementary miRNAs. These two lncRNAs can potentially serve as decoys for 21 different miRNAs, suggesting they may act as competing endogenous RNAs (ceRNAs) to regulate RNA transcription during PD pathogenesis [67].

\section{ncRNAs in AD pathogenesis}

$\mathrm{AD}$ is the most common cause of dementia in the elderly and affects the human population worldwide. Brain volume reductions in $\mathrm{AD}$ mainly result from hippocampal degeneration, and the major pathological features of this disease include extracellular amyloid- $\beta(\mathrm{A} \beta)$ plaques and hyperphosphorylated Tau in neurofibrillary tangles. AD patients often suffer progressive memory loss and acute cognition deficits during late-stage disease. Here we summarize the recent studies showing the involvement of ncRNAs in $\mathrm{AD}$ models; together, these studies suggest that ncRNAs play varied and important roles in the pathogenesis of $\mathrm{AD}$ (Table 3, Figs. 3 and 4).

\section{nCRNAs in the regulation of $A \beta$ generation and accumulation}

It is well documented that production of the $A \beta$ peptide is followed by secretion/release and extracellular precipitation. The Amyloid precursor protein (APP), a transmembrane protein, is processed by sequential cleavage by $\beta$-site APP cleaving enzyme-1(BACE1) and $\gamma$-secretase, to produce $A \beta$ [123]. Several ncRNA species regulate extracellular accumulation of $\mathrm{A} \beta$ in $\mathrm{AD}$ models by either promoting translation (Fig. 3a), disrupting clearance (Fig. 3b) or modulating secretase cleavage (Fig. 3c).

The ncRNA, $B C 1$, induces APP mRNA translation by associating with a fragile $\mathrm{X}$ syndrome protein (FMRP), and downregulation of $B C 1$ was found to induce $A \beta$ peptide accumulation and spatial learning and memory impairments in transgenic mice carrying mutant APP [83]. LncRNA-17A is mapped to the intron of G-proteincoupled-receptor 51 (GPR51). The upregulation of LncRNA-17A is linked to $A \beta$ secretion and elevation of $A \beta 42$ production. $A \beta 42$ is more toxic to neurons than $A \beta 40$, and the secreted $A \beta 42 / 40$ ratio is associated with high risk of $\mathrm{AD}$ in patients samples [124]. Moreover, treatment with $A \beta 42$ can stimulate lncRNA-17A expression to promote autophagy, neurodegeneration and deactivation of GABAB signaling, which occurs due to a GABAB receptor isoform switch based on alternative splicing [87, 88]. SORL1-AS (51A) is the antisense orientation of SORL1 intron 1 generated by alternative splicing. Upregulation of SORL1-AS decreases SORL1 expression by altering mRNA splicing, and by doing so, it impairs APP processing [98]. LRP1-AS is antisense RNA for Low-density lipoprotein receptor related protein 1 (LRP1), which disrupts LRP1mediated $A \beta$ clearance by directly binding to high-mobility group box 2 (Hmgb2) to block Srebpla-dependent transcription of LRP1. Thus, LRP1-AS upregulation in AD brain has been mechanistically linked to the promotion of $A \beta$ formation and decreased clearance $[101,102]$. In the APPswe/ PSEN1 $\triangle \mathrm{E} 9$ mouse model, MIAT also regulates $\mathrm{A} \beta$ clearance via its effects on LRP1 expression. MIAT downregulation promotes miR-150-5p/VEGF-mediated fibrillogenesis, decreases brain microvessel number and reduces expression of tight junction proteins. Thus, loss of MIAT increases $A \beta 40$ and $A \beta 42$ levels with a corresponding potentiation of neuronal loss in mouse model [90]. MicroRNA-106b is associated with APP generation and is downregulated in tissues from AD patients [116]. MicroRNA-200b/200c reduces $A \beta$ secretion and insulin resistance in the brain by inhibiting ribosomal protein S6 kinase B1 (S6K1)-dependent phosphorylation of insulin receptor substrate 1 (IRS-1) to suppress the signaling of IRS-1 at serine residues [114]. MicroRNA-33 enhances A $\beta$ clearance by promoting expression of ATP-binding cassette transporter A1 (ABCA1) and ApoE lipidation. The deletion of miR-33 has been linked to AD pathology in APPswe/PESN1 $\triangle \mathrm{E} 9$ mice [118].

Since extracellular precipitation of $A \beta$ is promoted by its secretion, the regulation of $A \beta$ secretion is an important factor in plaque formation. ncRNAs participate in this mechanism of regulating $\mathrm{AD}$ as well (Fig. 3c). Secretases are essential for $A \beta$ secretion, and modulation of BACE- 1 activity affects $A \beta$ secretion and plaque initiation. Brain cytoplasmic 200 RNA (BC200) is translational regulator in postsynaptic dendritic microdomains that regulates longterm synaptic plasticity. Upregulation of $B C 200$ promotes BACE-1 activity and plasticity failure in AD postmortem brain tissues. Moreover, $B C 200$ upregulation potentiates $A \beta 42$ expression via a direct promotion of BACE-1 expression and subsequent impairment of cell viability [84-86]. The level of neuroblastoma differentiation marker 29 
Table 3 ncRNAs and related processes in Alzheimer's disease

\begin{tabular}{|c|c|c|c|c|c|c|}
\hline & Name & $\begin{array}{l}\text { up/down } \\
\text { regulation }\end{array}$ & genetic mutation & Description & Model & Ref \\
\hline \multirow[t]{11}{*}{ LncRNAs } & $B C 1$ & up & Tg2576-APPswe & $\begin{array}{l}\text { Induces APP mRNA translation via association } \\
\text { with fragile } X \text { syndrome protein (FMRP). Induces } \\
\text { A } \beta \text { peptides accumulation and affects spatial } \\
\text { learning and memory impairments of mice. }\end{array}$ & mouse & [83] \\
\hline & $B C 200$ & up & & $\begin{array}{l}\text { Regulate cell vialbility via directly targeting } \\
\text { BACE1 mRNA expression. BC200 increases BACE1 } \\
\text { expression and enhances AB1-42 expressioin. }\end{array}$ & $A D$ brain section & [84-86] \\
\hline & LnCRNA -17A & up & $A \beta 1-42$ treatment & $\begin{array}{l}\text { Upregulates autophagy, deactivates GABAB } \\
\text { signaling and induces neurodegeneration. }\end{array}$ & neuroblastoma & {$[87]$} \\
\hline & LnCRNA -17A & up & $\begin{array}{l}\text { Inducing } \\
\text { inflammation } \\
\text { response }\end{array}$ & $\begin{array}{l}\text { Impaires GABAB signaling through mediating } \\
\text { receptor isoform switch via altering alternative } \\
\text { splcing, and further induce } A \beta \text { secretion and } \\
\text { increment of } A \beta 42 / 40 \text { ratio. }\end{array}$ & $\begin{array}{l}\text { AD brain section, } \\
\text { SH-SY5Y cells }\end{array}$ & [88] \\
\hline & MEG3 & up & $\begin{array}{l}\text { microinjection of } \\
A \beta 25-35\end{array}$ & $\begin{array}{l}\text { Inhibiting the PI3K/Akt signaling pathway and } \\
\text { apoptosis of hippocampal neurons, decreased } \\
\text { Aß expression, inhibited oxidative stress injury } \\
\text { and inflammatory injury. }\end{array}$ & rat & [89] \\
\hline & MIAT & down & APPswe/PSEN1 $\Delta$ E9 & $\begin{array}{l}\text { Regulates amyloid clearance via regulating low- } \\
\text { density lipoprotein receptor related protein } 1 \\
\text { (LRP1) expression and miR-150-5p/NEGF medi- } \\
\text { ated fibrillogenesis; Increased A } 340 \text { and A } A 42 \\
\text { levels and neuronal loss; Decreased brain micro- } \\
\text { vessel number and the expression of tight junc- } \\
\text { tion proteins. }\end{array}$ & mouse & {$[90]$} \\
\hline & NDM29 & up & - & $\begin{array}{l}\text { Induces APP synthesis and promotes cleavage } \\
\text { activity of BACE } 1 \text { and } \gamma \text {-secretase. Increase AB } \\
\text { secretion and increment of A } 42 / 40 \text { ratio. }\end{array}$ & $\begin{array}{l}\text { AD brain section, } \\
\text { mouse } \\
\text { neuroblastoma }\end{array}$ & [88] \\
\hline & NEAT1 & up & $A \beta 1-42$ treatment & $\begin{array}{l}\text { Mediates A } A \text { and pTau induced neuronal death } \\
\text { via acting as miR-107 decoy. }\end{array}$ & human cell line & [91] \\
\hline & NEAT1 & up & - & $\begin{array}{l}\text { Mediates A } \beta \text { secretion and pTau via regulating } \\
\text { miR-124/BACE1 regulation. }\end{array}$ & mouse model & [92] \\
\hline & NEAT1 & up & - & $\begin{array}{l}\text { Negetively regulating CDK5R1 mRNA level } \\
\text { through positively regulating miR-15/107. }\end{array}$ & AD brain & [93] \\
\hline & P3AlU/SINE & up in RPE & - & $\begin{array}{l}\text { Neurodegeneration via P3Alu-induced inflamma- } \\
\text { somes (in RPE; still a hypothesis in neurons) }\end{array}$ & $\begin{array}{l}\text { AD brain section, } \\
\text { mouse model }\end{array}$ & [94] \\
\hline \multirow[t]{8}{*}{ NATS } & BACE1-AS & up & $\begin{array}{l}\text { APP-KM670/ 671NL } \\
\text { and V717F }\end{array}$ & $\begin{array}{l}\text { Stabilizes BACE } 1 \text { mRNA and prevents miR- } 485-5 p \\
\text { targeting on BACE1 mRNA. Increased A } 342 \text { is } \\
\text { identified in the models. }\end{array}$ & $\begin{array}{l}\text { AD brain section, } \\
\text { mouse }\end{array}$ & {$[95,96]$} \\
\hline & BDNF-AS & up & - & In epigenetic level, promots BDNF depletion. & $\begin{array}{l}\text { mouse model, } \\
\text { HEK293T }\end{array}$ & [33] \\
\hline & EBF3-AS & up & $\begin{array}{l}\text { APPswe/PSEN1 } \triangle \text { E9, } \\
\text { A } 325-35 \text { treated cell }\end{array}$ & $\begin{array}{l}\text { Reduces EBF3 (early B cell factor 3) expression } \\
\text { and promots cell death. }\end{array}$ & mouse model, cell & {$[97]$} \\
\hline & $S O R L 1-A S(51 A)$ & up & - & $\begin{array}{l}\text { SORL1-AS is the antisense orientation in intron } 1 \\
\text { of the SORL1 gene and decrease SORL } \\
\text { expression via altering splicing. SORL1-AS overex- } \\
\text { pression results in impaired processing of APP } \\
\text { and increased A } \beta \text { formation. }\end{array}$ & $A D$ brain section & {$[98]$} \\
\hline & SOX21-AS1 & up & $A \beta 1-40$ treatment & $\begin{array}{l}\text { Reducing Frizzled } 3 / 5 \text { (FZD3/5) mediated Wnt } \\
\text { signaling pathwa and trigged oxidative stree and } \\
\text { cell death in hippocampal neurons. }\end{array}$ & mouse model & [99] \\
\hline & NAT-RAd18 & up & $A \beta 1-40$ treatment & $\begin{array}{l}\text { Promotes DNA damage via reducing Rad } 18 \\
\text { expresion, and leads to cell death. }\end{array}$ & Rat cortical neurons & {$[100]$} \\
\hline & LRP1-AS & up & - & $\begin{array}{l}\text { Disrupts LRP1 mediated A clarance via directly } \\
\text { binding to high-mobility group box } 2 \text { (Hmgb2) } \\
\text { and blocking the Srebp1a-dependent transcription } \\
\text { of LRP1. Promotes APP endocytic trafficking, in- } \\
\text { creases A } \beta \text { formation and decreases A } \beta \text { clearance. }\end{array}$ & $\begin{array}{l}\text { AD brain section, } \\
\text { Hmgb2 KO mice and } \\
\text { mouse RAW264.7 cell } \\
\text { line }\end{array}$ & {$[101,102]$} \\
\hline & $\begin{array}{l}\text { EBF3-AS, HAO2-AS, } \\
\text { AD-lic1, AD-linc2 }\end{array}$ & up & - & Promoting neuron apoptosis. & $A D$ brain section & [103] \\
\hline
\end{tabular}


Table 3 ncRNAs and related processes in Alzheimer's disease (Continued)

\begin{tabular}{|c|c|c|c|c|c|c|}
\hline & Name & $\begin{array}{l}\text { up/down } \\
\text { regulation }\end{array}$ & genetic mutation & Description & Model & Ref \\
\hline \multirow[t]{18}{*}{ microRNAs } & let-7b & up & - & $\begin{array}{l}\text { Activating RNA-sensing Toll-like receptor } 7 \text { and } \\
\text { neuronal death. }\end{array}$ & $\begin{array}{l}\text { AD CSF, mouse } \\
\text { model, macrophages }\end{array}$ & [104] \\
\hline & miR-106b & up & Tg-APPswe/PS $\Delta$ E9 & $\begin{array}{l}\text { Regulate TGF- } \beta \text { signaling pathways and reduce } \\
\text { phosphprylation of Smad } 2 / 3 \text { and smad } 6 / 7 \text { for } \\
\text { promoting neurodegenration. }\end{array}$ & mouse models & [105] \\
\hline & miR-106b & down & - & $\begin{array}{l}\text { Regulates tau phosphoryation via targeting Fyn } \\
\text { (tyrosine kinase) and increase pTau. }\end{array}$ & $\begin{array}{l}\text { AD brain section, } \\
\text { human cell line }\end{array}$ & [106] \\
\hline & miR-128 & up & $3 \times \operatorname{Tg}-A D$ & $\begin{array}{l}\text { Reducing APP expression, A } \beta \text { production and } \\
\text { inflammatory response via tardeting peroxisome } \\
\text { proliferator-activated receptor gamma (PPAR }) \\
\text { expression. }\end{array}$ & mouse model & [107] \\
\hline & $\begin{array}{l}\text { miR-34a, mlr132/ } \\
212\end{array}$ & down & $\begin{array}{l}\text { 3x Tg-AD } \\
\text { (PSEN1(PS1M146V), } \\
\text { APP (APPSwe) and } \\
\text { Tau (P301L) }\end{array}$ & $\begin{array}{l}\text { Correlated with } A \beta \text { production via targeting Sirt. } \\
\text { Sirt can regulate } A \beta \text { production. }\end{array}$ & mouse model & {$[108,109]$} \\
\hline & miR-132/212 & down & $\begin{array}{l}\text { 3x Tg-AD } \\
\text { (PSEN1(PS1M146V), } \\
\text { APP (APPSwe) and } \\
\text { Tau (P301L) }\end{array}$ & $\begin{array}{l}\text { Regulating Tau expression via direct interaction } \\
\text { and association with GSK-3 } \beta \text { and PP2B mediated } \\
\text { tau phosphorylation. }\end{array}$ & $\begin{array}{l}\text { AD brain section, } \\
\text { mouse model, } \\
\text { mouse } \\
\text { neuroblastoma }\end{array}$ & [110] \\
\hline & $\begin{array}{l}\text { miR-142a-5p, } \\
\text { miR-146a-5p, } \\
\text { miR-155-5p, miR- } \\
455-5 p\end{array}$ & up & $\begin{array}{l}\text { APPswe/PS1L166P, } \\
\text { THY-Tau22 }\end{array}$ & May be part of a protective response in AD. & $\begin{array}{l}\text { AD brain section, } \\
\text { mouse model }\end{array}$ & [110] \\
\hline & miR-15/107 & down & - & $\begin{array}{l}\text { Increase expression of CDK5R1/p35 and } \\
\text { consequently enhance CDK5 activity. miR-15/107 } \\
\text { also modulates BACE1 expression and increase } \\
\text { APP protein expresin and pTau formation. }\end{array}$ & $\begin{array}{l}\text { AD brain section, } \\
\text { human cell lines }\end{array}$ & {$[111,112]$} \\
\hline & miR-16 & down & & $\begin{array}{l}\text { Attenuate } A \beta \text { mediated neurotoxicity via } \\
\text { reducing BACE1 expression. }\end{array}$ & post morten tissue & [113] \\
\hline & $\mathrm{miR}-200 \mathrm{~b} / \mathrm{c}$ & up & $\begin{array}{l}\text { A } \beta \text { treatment/ } \\
\text { Tg } 2576 \text { transgenic } \\
\text { mice }\end{array}$ & $\begin{array}{l}\text { miR-200b/c inhibits S6K1-dependent phosphoryl- } \\
\text { ation of IRS-1, suppresse IRS-1 pSer signaling } \\
\text { pathway and cause insulin resistance in the } \\
\text { brain. A } 3 \text { secretion is corelated in the models. }\end{array}$ & $\begin{array}{l}\text { mouse model, } \\
\text { mouse cell lines }\end{array}$ & [114] \\
\hline & $\operatorname{miR}-25$ & up & $A \beta 1-42$ induction & $\begin{array}{l}\text { Downregulating KLF2 via Nrf2 signaling pathway } \\
\text { to suppress proliferation and promot apoptosis. }\end{array}$ & mouse model & [115] \\
\hline & miR-29a/b-1 & down & - & Decreases BACE1 expression. & $A D$ brain section & [116] \\
\hline & $\operatorname{miR}-29 c$ & down & - & $\begin{array}{l}\text { Regulating the expression of BACE1 by directly } \\
\text { targeting its } 3^{\prime} U T R \text { and promoting cell } \\
\text { proliferation via PKA signaling. Increasing BACE1 } \\
\text { level via PKA/CREB signaling pathway. }\end{array}$ & $\begin{array}{l}\text { Peripheral blood of } \\
\text { AD pateints, SAMP } \\
\text { mouse model }\end{array}$ & [117] \\
\hline & miR-33 & deletion & $\begin{array}{l}\text { miR-33(-/-); } \\
\text { APPswe/PSEN1 } \Delta \text { E9, }\end{array}$ & $\begin{array}{l}\text { Increasing ATP-binding cassette transporter A1 } \\
\text { (ABCA1) expression, ApoE lipidation, and decrea- } \\
\text { seing A level. }\end{array}$ & $\begin{array}{l}\text { mouse and human } \\
\text { neural cells }\end{array}$ & [118] \\
\hline & miR-34a & up & APPswe/PSEN1 $\Delta$ E9 & 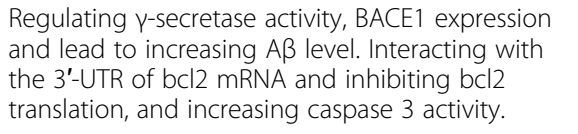 & mouse model & {$[119,120]$} \\
\hline & miR-485-5p & down & - & $\begin{array}{l}\text { miR-485-5p is corelated to BACE1 } \\
\text { upregulation. The expression of two } \\
\text { competitively regulatory RNAs, miR-485-5p and } \\
\text { BACE1-AS, are dysregulated. }\end{array}$ & $A D$ brain section & [96] \\
\hline & miR-873-5p & down & $A \beta 1-42$ induction & $\begin{array}{l}\text { Preveting apoptosis via targeting Heme } \\
\text { oxygenase } 1 \text { (HMOX1) expression level. }\end{array}$ & $\begin{array}{l}\text { mouse model, rat } \\
\text { cell line }\end{array}$ & [121] \\
\hline & miR-338-5p & down & $\begin{array}{l}\text { 5XFAD transgenic } \\
\text { (TG) mice }\end{array}$ & $\begin{array}{l}\text { Mediaing amyloid formation via targeting BACE1; } \\
\text { associtaed with NF-kB signaling pathway activa- } \\
\text { tion. Doenregulated miR-338-5p increases BACE1 } \\
\text { expression, A } \beta \text { formation, and } \\
\text { neuroinflammation. }\end{array}$ & $\begin{array}{l}\text { AD brain section, } \\
\text { mouse }\end{array}$ & [122] \\
\hline
\end{tabular}


(NDM29) is increased by inflammation. In $\mathrm{AD}$ patient brains, NDM29 upregulation induces APP synthesis and promotes its cleavage by BACE1 and $\gamma$-secretase. Upregulation of $B C 200$ or NDM29 increase $A \beta$ secretion and the A $\beta 42 / 40$ ratio [85, 86]. BACE1-AS is a conserved RNA transcribed from the opposite strand of the BACE1 locus on chromosome 11 (11q23). BACE1-AS increases BACE1 expression by stabilizing BACE1 $\mathrm{mRNA}$ and prevents miR485-5p-mediated degradation. Upregulation of BACE1-AS thus leads to high $\mathrm{A} \beta 42$ levels in $\mathrm{AD}$ brain tissue and mouse models [95]. BACE1-AS and miR-485-5p competitively regulate $\mathrm{BACE}-1$, and the dysregulation of each is associated with increased BACE1 expression in AD brain sections [96]. Cyclin-dependent kinase 5 regulatory subunit 1 (CDK5R1) encodes for p35 and is an activator of CDK5. MicroRNA-15/107 negatively regulates CDK5R1 expression via direct targeting of its 3'UTR. Using AD brain sections, it was shown that CDK5R1 increases the levels of p35/CDK5, which consequently enhances CDK5 activity and modulates BACE-1 expression [111]. Further studies have linked microRNAs to reduced BACE-1 expression by direct targeting from molecules such as miR-29a/29b1/c. The downregulation of miR-29a/29b1/c leads to $A \beta$ accumulation in peripheral blood of $\mathrm{AD}$ patients, postmortem brain tissues and the SAMP mouse model [117]. miR-16 can reduce BACE1 expression and attenuate $A \beta$-mediated neurotoxicity. miR-338-5p also regulates BACE-1 expression by targeting its mRNA, and expression of this microRNA leads to increased $A \beta$ formation in brain tissues [122]. Downregulated miR-29a/29b1/c, miR-338-5p and miR-16 are all linked to increased $A \beta$-mediated neurotoxicity in vitro and in vivo [113]. Among those microRNAs, miR338-5p also regulates NF- $\mathrm{kB}$ signaling and promotes neuroinflammation [122]. In vivo studies with mouse models also showed that miR-34a promotes $A \beta$ accumulation and cognition by promoting BACE- 1 expression and $\beta$-secretase activity. MiR-128 further reduces $A \beta$ expression and inflammatory response through effects on $\gamma$-peroxisome proliferator-activated receptor (PPAR $\gamma$ ) expression [107]. Sirt1 (also known as Sirtuin 1), a nicotinamide adenine dinucleotide-dependent deacetylase, regulates $A \beta$ production, and miR-132/212 are correlated with $A \beta$ production via direct targeting of Sirt 1 . The downregulation of miR$132 / 212$ fails to reduce $A \beta$ production, and is linked to $\mathrm{AD}$ pathogenesis in a triple-transgenic mouse model carrying PSEN1(PS1M146V), APP (APPSwe) and Tau (TauP301L) expression constructs [108, 109].

\section{ncRNAs in the regulation of tau expression and post- translational modification (PTM)}

Microtubule-associated protein Tau (Tau/MAPT) is highly expressed in neurons and functions as a microtubule stabilizer. Neurofibrillary tangles comprise one of the key $\mathrm{AD}$ pathological signs, and are caused by hyperphosphorylation of Tau (pTau). Although the origin of pTau is still unclear, it is often observed alongside $A \beta$ accumulation [123]. A subset of ncRNAs promotes kinase activities and thus leads to pTau (Fig. 4a). NEAT1 has been shown to act as a microRNA decoy for miR107, which is downregulated in AD brain tissues [125]. Upregulation of NEAT1 corresponds to increased miR107 activity and contributes to enhancement of $A \beta$ expression, pTau and neuronal death [91]. MicroRNA-124 has shown neuroprotective effects, which are due to decreased BACE-1 expression and further reduction of $A \beta$ secretion in AD mouse models [126]. NEAT1 is also a negative regulator of miR-124 and consequently promotes BACE-1 expression. Thus, the upregulation of NEAT1 is linked to both $\mathrm{A} \beta$ secretion and pTau in $\mathrm{AD}$ mouse models [92]. Furthermore, Tau upregulation may increase the frequency of pTau, and microRNAs have been shown to affect Tau levels to indirectly modulate pTau. MicroRNA-132/212 was shown to regulate Tau expression by directly targeting Tau mRNA in tripletransgenic AD mice. Downregulation of microRNA-132/ 212 is associated with GSK-3 $\beta$-mediated increases in pTau $[108,110]$. MicroRNA-106b targets Fyn (a Src family tyrosine kinase), which in turn, regulates Tau phosphorylation; thus, the downregulation of micRNA-106b is associated with Fyn upregulation and promotion of pTau formation [106].

\section{ncRNAs in the regulation of AD-associated apoptosis}

A number of ncRNA subtypes are known to regulate cellular pathways involved in $\mathrm{AD}$ neurodegeneration (Fig. 4b). Antisense transcript of SOX21 (SOX21-AS) reduces Frizzled 3/5 (FZD3/5)-mediated Wnt signaling and triggers oxidative stress generation. This increased oxidative stress subsequently promotes apoptosis in hippocampal neurons within an AD model [99]. Antisense transcript of EBF3 (EBF3-AS) reduces early B cell factor 3 (EBF3) mRNA expression and promotes cell death. In an $\mathrm{AD}$ mouse model and $\mathrm{A} \beta$-treated cells, EBF3- $A S$ upregulation was found to promote apoptosis [97, 103]. NAT-RAd18 is an antisense transcript of RAd18. After A $\beta 40$ treatment of rat cortical neurons, upregulated NAT-RAd 18 promotes DNA damage by reducing RAd18 expression, leading to cortical neuron death [100]. In a rat model with microinjection of A $\beta 25-35, M E G 3$ is downregulated. Exogenous MEG3 functionally protects neurons by inhibiting the PI3K/Akt signaling pathway and preventing apoptosis of hippocampal neurons. MEG3 also decreases $\mathrm{A} \beta$ expression and diminishes injury from oxidative stress and inflammation [89]. Using AD postmortem tissue, it was found that NEAT1, HOTAIR and MALAT1, all negatively regulate the CDK5R1/p35 complex and promote cell death by controlling expression of the miR-15/107 family [93]. 
MicroRNAs are implicated in AD-associated apoptosis as well. $\mathrm{Bcl} 2$ is an anti-apoptotic protein primarily localized to mitochondria, and its expression is known to protect cell viability by opposing caspase-9-initiated apoptosis [127]. MicroRNA-34a negatively regulates $\mathrm{Bcl} 2$ expression through direct targeting of its 3'UTR. In $\mathrm{AD}$ transgenic mice, $\mathrm{Bcl} 2$ downregulation leads to caspase 3 activation and neurodegeneration [119, 120]. Moreover, miR-25 directly targets KLF2 and Nrf2, which are associated with hippocampal neuron proliferation. A $\beta 42$ treatment upregulates miR-25 to promote cell death in mouse models [115]. Upregulation of Heme oxygenase 1 (HMOX1) has been linked to cognitive function and downregulation of miR183-5p in an AD mouse model. In the AD mouse, overexpressed miR-873-5p targets HMOX1 mRNA and impairs cognition. Thus, miR$873-5 p$ has been suggested as a protective factor in the central nervous system [121]. TGF- $\beta$ signaling pathway plays a key role in the AD pathogenesis, and miR-106b directly targets the 3'UTR of TGF $\beta$-II mRNA. miR106b-dependent TGF- $\beta$ signaling reduces phosphorylation of Smad2/3 and Smad6/7 to promote neurodegeneration in APPswe/PS $\triangle \mathrm{E} 9 \mathrm{AD}$ mice [105]. Toll-like receptors (TLRs), which are innate immune receptors, have been shown to accelerate and spread central nervous system damage induced by brain-derived factors. In an AD mouse model, the RNA-sensing TLR7 is activated by extracellular let-7 and promotes neurodegeneration. Cerebrospinal fluid of $\mathrm{AD}$ patients contains higher amounts of let-7 compared with healthy individuals, so the microRNA let-7 has been suggested to be an important activator of TLR7-mediated damage in AD [104].

\section{ncRNAs in other mechanisms of $A D$ pathogenesis}

The Alu-derived RNA, P3Alu, activates ERK1/2 signaling and the formation of the NLRP3 inflammasome in retinal pigment epithelium. Other Alu RNAs, BC200 and NDM29, are also known to be upregulated and involved in signaling during AD pathogenesis. Thus, neurodegeneration may be facilitated by Alu-induced inflammation [94]. BDNF-AS is a conserved noncoding antisense RNA transcript of BDNF. BDNF-AS represses BDNF transcription by modulating $\mathrm{H} 3 \mathrm{~K} 27 \mathrm{me} 3$ at the BDNF locus and recruiting EZH2 to the BDNF promoter region. Knockdown of BDNF-AS restores BDNF transcription and promotes neurite outgrowth [33]. Since NEAT1 upregulation has been linked to several signaling pathways in $\mathrm{AD}$, it has been suggested as an $\mathrm{AD}$ biomarker and potential therapeutic target [92].

\section{nCRNAs in the pathogenesis of other neurodegenerative diseases}

FTLD is a common type of cortical dementia with disease onset often occurring before 65 years of age.
Approximately half of all FTLD cases are associated with TDP43 inclusions, which is also a hallmark of ALS. Thus, FTLD and ALS may be categorized together as TDP43 proteinopathies [128]. The most common genetic cause of ALS and FTLD is a mutation in C9orf72, which comprises a hexanucleotide repeat expansion (HRE) GGGGCC (G4C2) in intron 1. The HRE ncRNA assembles in a G-quadruplex (G4) structure and disrupts nuclear import of proteins by sequestering GTPase activator for RAN (RANGAP1), which is essential for RAN-dependent protein/RNA nuclear import and export. Cytoplasmic accumulation of TDP43 is observed in cells with HRE and may be rescued by disrupting the HRE-RANGAP1 interaction with a cationic porphyrin, TMPyP4 [129]. HRE may also be translated into several distinct toxic dipeptides by random nonATG-initiated translation, leading to neurodegeneration. HRE translation is regulated by the CDC73/ PAF1 complex (PAF1C), a transcriptional regulator of RNA polymerase II, and this mechanism was shown to promote neurodegeneration in fly and mouse models [130]. Using tissues from postmortem ALS/ FTLD patients, TDP43 was associated with upregulation of the snRNA U12 and the ncRNA Hsrw (stressinduced satellite III repeat RNA), both of which are linked to neurodegeneration in ALS/FTLD. Mechanistically, upregulation of U12 snRNA and Hsrw is caused by an interaction between TDP43 and transcription elongation factor ELL2, a shared component of the little elongation complex and super elongation complex [131]. Using iCLIP in FTLS-TDP/ALS postmortem tissues, it was also shown that NEAT1 interacts with TDP43 and FUS/TLS [132, 133]. Since NEAT1 is essential for paraspeckle formation, NEAT1+ paraspeckle may be involved in ALS and FTLD etiology [134, 135]. In another example, ribonuclease angiotensin cleavage produces tiRNAs from tRNAs, which assemble as G4 structures and inhibit translation by displacing eIF4F from capped mRNA. Translational repressor Y-box 1 (YB-1) interacts with and is stabilized by tiRNAs. This interaction leads to stress granule formation and promotes motor neuron degeneration [136]. In ALS, the antisense transcript of CCND1 (ncRNACCND1) represses CCND1 transcription by recruiting FUS/TLS to the CCND1 promoter domain and inhibiting CREB-binding protein and p300 histone acetyltransferase activities. FUS/TLS mislocalization is a phenotype of the FUS-related ALS subtype, and CCND1 is important in DNA damage response. As such, ncRNACCND1-mediated CCND1 downregulation is linked to DNA damage and apoptosis in cellular models of FUS-related ALS [137].

Furthermore, dysregulated ncRNAs (Lhxlas, lncMN-1, and $\operatorname{lncMN2}$ ) have been identified in FUS-P517L ALS mouse models, but the consequences are unknown 
[138]. CircRNAs are also known to be dysregulated in FUS-mutated cells and motor neurons derived from ALS-iPSCs, but the functional roles of those circRNAs are still unclear as well [139]. In samples from ALS patients, the profiles of ncRNA expression shed light on how ALS pathogenesis may vary based on the genetic basis of disease. NATs provide a good example of how such insights may be gained. In FUS-mutated patients, $P A X B P-A S$ is the antisense of PAX3/PAX7 binding protein (PAXBP), which is a transcriptional factor that regulates chromosome binding. PAXBP-AS regulation of PAX3/7 pathways has been implicated in developing FUSALS. In ALS-TDP43 patients, SNAP25-AS is downregulated compared with healthy subjects. Because SNAP25 regulates synaptic vesicle processing and axonal repair, these cellular processes are likely to be negatively affected by TDP43 mutation in ALS motor neurons. In ALSSOD1, CKMT2, a mitochondrial creatine kinase (MtCK), and its antisense transcript (CKMT2-AS) have been linked to mitochondrial dysfunction and subsequent motor neuron degeneration. In sporadic ALS, IER3-AS is involved in regulating cell survival via promotion of $\mathrm{NFKB}$ expression; $\mathrm{NF}_{\mathrm{K}} \mathrm{B}$ regulation of apoptosis is thought to be important in sporadic ALS. ZBTB11-AS is potentially involved in DNA binding and regulation of transcription based on the known function of its target, Zinc Finger and BTB Domain containing 11 (ZBTB11) [140]. Although the functional impacts of the aforementioned antisense transcripts are still unknown, the regulatory pathways that the corresponding sense RNAs contribute to offer starting points for investigations into the pathogenic mechanisms of ALS [140].

MicroRNAs have been implicated in ALS pathogenesis as well. Cytoplasmic neurofilament aggregation is a major characteristic of ALS, and misregulated neurofilament proteins may serve as a potential diagnostic biomarker for ALS [141]. Upregulation of NEFM (neurofilament triplet M protein) and NEFH (neurofilament triplet $\mathrm{H}$ protein) has been detected in ALS spinal cord tissues. NEFM is reduced by miR-92a-3p and miR-125b-5p, and the NEFH 3'UTR is targeted by miR-124-3p, miR-92a-3p, miR-20b-5p and miR-223b-3p. The downregulation of miRNAs alters the stoichiometry of neurofilament expression and leads to the formation of pathogenic aggregates in ALS [142]. Tumor suppressor gene NDRG2 and miR-375-3p are dysregulated in a sporadic ALS mouse model carrying the Vps54 mutation. Upregulated NDRG2 increases reactive oxygen species formation and promotes p53 activity. Interestingly, insufficient targeting of p53 by miR-375-3p leads to upregulation of NDRG2 and reactive oxygen species production [143]. In FUS ${ }^{\mathrm{P} 525 \mathrm{~L}}$ motor neurons, miR375 serves to protect motor neurons from apoptosis through targeting of p53 and ELAVL4 [144].
Importantly, several studies have shown that microRNAs can alter lifespan in ALS/FTLD laboratory models. For instance, AAV-mediated expression of the miR17-92 cluster prolongs lifespan of SOD $1^{\text {G93A }}$ mice. This cluster targets an E3 ubiguitin ligase to regulate monoubiquitination of PTEN, which determines the subcellular location of the protein. By this mechanism, miR17-92 is able to regulate motor neuron vulnerability in ALS $[145,146]$. In another example, treatments to suppress miR-155, which is upregulated in ALS model rodents and patient spinal cord, improve survival in SOD $1^{\mathrm{G} 93 \mathrm{~A}}$ rodent models mainly by blocking miR-155 function in microglia, astrocytes and neurons [22, 147]. Another study in ALS-SOD1 ${ }^{\text {G93A }}$ rodent models showed that miR-155 regulates microglia expression of survival genes, including P2ry12, Tmem119, Olfml3, Egr1, Atf3, Jun, Fos, Mafb and Tgfbr1 [22]. Antisense oligonucleotides of miR-155 successfully inhibit miRNA function in spinal cord and brain, and improvements in survival time suggest that miR-155 may be a viable therapeutic target for ALS. Furthermore, microRNAs may be transported in extracellular vesicles and potentially spread pathogenic factors to neighboring cells. In ALS, upregulated miR-218 is transported from motor neurons to neighboring astrocytes, where it is sufficient to downregulate glutamate transporter, excitatory amino acid transport 2 (EAAT2). Blocking miR-218 with antisense oligonucleotides rescues EAAT2 expression and mitigates astrogliosis in mouse brain [148]. Neuromuscular synapses between motor neurons and muscle tissue are essential for motor neuron and muscle function. Exogenous expression of miR-206 slows ALS progression by regulating histone deacetylase $4 \mathrm{ex}-$ pression and fibroblast growth factor signaling. In response to motor neuron injury, miR-206 can promote a compensatory response in neuromuscular synapses and restore the function of neuromuscular junctions [149]. Spinal muscular atrophy (SMA) is a group of neuromuscular diseases caused by genetic mutations that compromise survival of motor neurons. U1 snRNA (U1) is essential for regulating pre-mRNA splicing, and its variant snRNAs (vU1s) are inversely correlated with U1 expression. The ratio of $\mathrm{vU} 1 / \mathrm{U} 1$ is dysregulated in SMA-iPSC-derived motor neurons compared with healthy controls. Upregulated vU1 snRNA is also observed in SMA-subjects, and thus, vU1 may contribute to SMA pathogenesis [150]. Spinocerebellar ataxia type 2 (SCA2) is caused by a CAG expansion in ataxin-2 (ATXN-2). Interestingly, ATXN2-AS transcripts with CAG repeats form RNA foci that induce caspase3/7-dependent apoptosis in cerebellar Purkinje cells [151].

Collectively, this growing body of studies shows that ncRNAs contribute to neurodegeneration in many types of dementia and lower motor neuron disease. Thus, ncRNA-based treatments may have potential to improve 
Table 4 ncRNAs and related processes in other neurodegenerative diseases

\begin{tabular}{|c|c|c|c|c|c|c|c|}
\hline Disease & $\begin{array}{l}\text { ncRNA } \\
\text { class }\end{array}$ & Name & $\begin{array}{l}\text { up/down } \\
\text { regulation }\end{array}$ & Mutation & Description & Model & Ref \\
\hline \multirow[t]{13}{*}{$\overline{\mathrm{ALS}}$} & NATs & $\begin{array}{l}\text { IER3-AS, ZBTB11- } \\
\text { AS, PAXBP-AS, } \\
\text { SNAP25-AS, } \\
\text { CKMT2-AS, }\end{array}$ & $\begin{array}{l}\text { down, } \\
\text { down, up, } \\
\text { down, } \\
\text { down }\end{array}$ & $\begin{array}{l}\text { SALS, TDP43, } \\
\text { SOD1, FUS }\end{array}$ & $\begin{array}{l}\text { IER3-AS and ZBTB11-AS downregulated in } \\
\text { sporadic ALS; PAXBP-AS upregulaed in ALS- } \\
\text { FUS; SNAP25-AS downregulated in ALS-FUS; } \\
\text { CKMT2-AS downregulated in ALS-SOD1. The } \\
\text { mechnisms are still unkown. }\end{array}$ & $\begin{array}{l}\text { ALS spinal cord } \\
\text { extract, peripheral } \\
\text { blood } \\
\text { mononuclear cells }\end{array}$ & [140] \\
\hline & \multirow[t]{3}{*}{ LncRNAs } & ncRNA $A_{C C N D 1}$ & up & FUS/TLS & $\begin{array}{l}\text { In response to DNA damage, nCRNA } A_{C C N D 1} \\
\text { interactes with FUS and represses CCND1 } \\
\text { transcription by enhancing inhibition of CBP } \\
\text { and p300 histone acetyltransferase activities. }\end{array}$ & & [137] \\
\hline & & $\begin{array}{l}\text { tiRNAs (tRNA- } \\
\text { derived RNA } \\
\text { fragments) }\end{array}$ & up & ANG-P112L & $\begin{array}{l}\text { tiRNAs inhibit translation via its G-guadruplex } \\
\text { structure. tiRNAs displace elF4 from mRNA } \\
\text { and stablizes YB-1. tiRNAs promotes the un- } \\
\text { translated mRNA for stress granule formation. }\end{array}$ & cell line & [136] \\
\hline & & $\begin{array}{l}\text { Lhx1as, LncMN- } \\
\text { 1, LncMN2 }\end{array}$ & & Fus P517L & $\begin{array}{l}\text { detected in mouse model without know } \\
\text { mechanisms. }\end{array}$ & mouse & [138] \\
\hline & \multirow[t]{9}{*}{ MicroRNAs } & miR-17 92 & down & $\begin{array}{l}\text { SOD } 1^{\mathrm{G} 93 \mathrm{~A}} \\
\text { SOD } 1^{\mathrm{L144F}}\end{array}$ & $\begin{array}{l}\text { miR-17 92 cluster target E3 ubiguitin ligase to } \\
\text { regulate PTEN subcellular location via } \\
\text { monoubiquitination. miR-17 92/nuclear PTEN } \\
\text { regulats motor neuron vulnerability in } \\
\text { SOD1ALS. }\end{array}$ & $\begin{array}{l}\text { ALS patienst's } \\
\text { iPSC, mouse } \\
\text { model }\end{array}$ & {$[145,146]$} \\
\hline & & miR-155 & up & $\mathrm{SOD} 1^{\mathrm{G} 93 \mathrm{~A}}$ & $\begin{array}{l}\text { miR-155 distributes in rodent and patients' } \\
\text { spinal cord. Anti-miR-155 treatement improve } \\
\text { survival rate by mainly blocking miR-155 fun- } \\
\text { cion in microglia, astrocyte and neuron. }\end{array}$ & $\begin{array}{l}\text { ALS spinal cord, } \\
\text { rodent model }\end{array}$ & [147] \\
\hline & & miR-155 & up & $\mathrm{SOD} 1^{\mathrm{G} 93 \mathrm{~A}}$ & $\begin{array}{l}\text { miR-155 regulates survival gene expression in } \\
\text { microglia incuding P2ry12, Tmem119, Olfml3, } \\
\text { Egr1, Atf3, Jun, Fos, and Mafb and Tgfbr1. }\end{array}$ & $\begin{array}{l}\text { ALS spinal cord, } \\
\text { rodent model }\end{array}$ & [22] \\
\hline & & miR-206 & down & & $\begin{array}{l}\text { miR-206 contols HDAC4 expression in } \\
\text { neuromuscular gene expression and restore } \\
\text { the NMJ function. }\end{array}$ & mouse model & [149] \\
\hline & & miR-218 & up & $\mathrm{SOD} 1^{\mathrm{G} 93 \mathrm{~A}}$ & $\begin{array}{l}\text { miR-218 can be transported from motor } \\
\text { neurons to neighbouring astrocytes and } \\
\text { sufficiently downregulates glutamate } \\
\text { transporter in astrocytes (excitatory amino } \\
\text { acid transport } 2 \text { (EAAT2)). Blocking miR-218 } \\
\text { with antisense oligonucleotides recover EAAT2 } \\
\text { expression and mitigates astrogliosis in mouse } \\
\text { brain. }\end{array}$ & mouse model & [148] \\
\hline & & miR-375-3p & down & Vps54 & $\begin{array}{l}\text { tumor suppressor gene NDRG2 and miR-375- } \\
3 p \text { are dysregulated in sporadic ALS. Upregu- } \\
\text { lated NDRG2 increas ROS formation and fur- } \\
\text { ther activates p53. Insufficient targeting p53 } \\
\text { by miR-365-3p leads to NDRG2 and ROS } \\
\text { upregulation. }\end{array}$ & ALS-iPSC & [143] \\
\hline & & miR-375 & down & FUS $^{P 525 L}$ & $\begin{array}{l}\text { miR-375 targets p } 53 \text { and ELAVL4, which are } \\
\text { upregulated due to loss of FUS function. }\end{array}$ & ALS-iPSC & [144] \\
\hline & & $\begin{array}{l}\text { miR-92a-3p, } \\
\text { miR-125b-5p, }\end{array}$ & down & & $\begin{array}{l}\text { miR-92a-3p and miR-125b-5p target NEFM } \\
\text { 3'UTR. }\end{array}$ & ALS spinal cord & [142] \\
\hline & & $\begin{array}{l}\text { miR-124-3p, } \\
\text { miR-92a-3p, } \\
\text { miR-20b-5p } \\
\text { miR-223b-3p, }\end{array}$ & down & & $\begin{array}{l}\text { miR-124-3p, miR-92a-3p, miR-20b-5p and miR- } \\
\text { 223b-3p target NEFH 3'UTR. }\end{array}$ & ALS spinal cord & [142] \\
\hline \multirow[t]{3}{*}{$\begin{array}{l}\text { ALS; } \\
\text { FTLD }\end{array}$} & \multirow[t]{3}{*}{ LncRNA } & $\begin{array}{l}\text { C9ORF72 } \\
\text { (repeat } \\
\text { expansion) }\end{array}$ & up & $\begin{array}{l}\text { hexanucleotide } \\
\text { repeat } \\
\text { expansion in } \\
\text { C9orf72 intron } 1\end{array}$ & $\begin{array}{l}\text { HRE repeats expansion disrupts RAN } \\
\text { dependent protein/RNA nucleaocytoplasmic } \\
\text { transport by sequestering RNAGAP1 and leads } \\
\text { to neurodegeneration. HRE also get translated } \\
\text { into toxic dipeptide by interacting with PAC1 } \\
\text { depedent translation factor and leads to } \\
\text { neurodegeneration. }\end{array}$ & $\begin{array}{l}\text { ALS patients' } \\
\text { brain, spinal cord; } \\
\text { iPSC, mouse, fly }\end{array}$ & {$[129,130]$} \\
\hline & & MALAT1, MEG3 & & TDP43 & $\begin{array}{l}\text { In iCLIP data, MALAT1 inteactes with TDP43, } \\
\text { and FUS interactes with MEG3. }\end{array}$ & $\begin{array}{l}\text { ALS patinets' } \\
\text { tissue extract }\end{array}$ & {$[132,133]$} \\
\hline & & NEAT1 & up & TDP43, FUS & $\begin{array}{l}\text { NEAT1_2 interacte with TDP } 43 \text { and FUS by } \\
\text { iCLIP data. TDP43 and FUS are recruited to }\end{array}$ & $\begin{array}{l}\text { ALS patients' } \\
\text { tissue extract }\end{array}$ & [132-135] \\
\hline
\end{tabular}


Table 4 ncRNAs and related processes in other neurodegenerative diseases (Continued)

\begin{tabular}{|c|c|c|c|c|c|c|c|}
\hline Disease & $\begin{array}{l}\text { ncRNA } \\
\text { class }\end{array}$ & Name & $\begin{array}{l}\text { up/down } \\
\text { regulation }\end{array}$ & Mutation & Description & Model & Ref \\
\hline & & & & & paraspeckle due to interaction with NEAT1_2. & & \\
\hline & snRNA & $\begin{array}{l}\text { U12 snRNA, } \\
\text { Hsrw }\end{array}$ & up & TDP43 & $\begin{array}{l}\text { associated with neurodegeneration caused by } \\
\text { TDP } 43 \text { promoted transcrption elongation via } \\
\text { interaction with ELL2 in elongation } \\
\text { complexes. }\end{array}$ & Fly & [131] \\
\hline SMA & snRNA & $\begin{array}{l}\text { variant of U1 } \\
\text { snRNA (VU1) }\end{array}$ & up & & $\begin{array}{l}\text { variant of U1 snRNA (VU1) is upregulated and } \\
\text { affects U1 snRNA expression. The ratio of VU1/ } \\
\text { U1 increased in SMA-iPSC derived MN com- } \\
\text { pared with control. }\end{array}$ & SMA-iPSC & [150] \\
\hline SCA2 & NATs & ATXN2-AS & & & $\begin{array}{l}\text { ATXN1-AS transcripts with CAG repeats forms } \\
\text { RNA foci and detected in SCA2 cerebellar } \\
\text { Purkinje cell. ATXN1-AS and CAG repeats trig- } \\
\text { ger caspase } 3 / 7 \text { dependent apoptosis. }\end{array}$ & SCA2 tissues & [151] \\
\hline
\end{tabular}

lifespan and disease symptoms. The ncRNAs known to participate in the aforementioned diseases are summarized in Table 4. Although there are still no effective drugs for any of these diseases, promising results from animal models can provide potential targets for future therapeutic development.

\section{Conclusions and future perspectives}

Accumulating evidence demonstrates that ncRNAs play important roles in the central nervous system and regulate neurodegeneration. In this work, we have summarized recent studies elucidating the varied roles of ncRNAs in neurodegenerative diseases, including HD, PD, AD, ALS, FTLD, SCA2 and SMA. Development of ncRNA-based treatments for neurodegenerative diseases may represent a novel and potentially effective therapeutic strategy, which could also further our understanding ncRNA biology [152]. Recent studies on ncRNAs in neurodegenerative diseases have mostly focused on miRNAs as decoys [12] and/or transcriptional regulators [25, 30, 153]. Systems biology and bioinformatics approaches will be required to unravel the functional roles of a wider class of ncRNAs and complex RNA networks in each disease state [154]. Moreover, valuable insights into the spatial context of RNA expression may be gained by novel technologies, such as single-cell sequencing [155] and spatial transcriptome sequencing [156]. Finally, novel drug delivery technologies can be developed to effectively target ncRNAs to specific regions [157]. For example, oligonucleotide modifications can be used to improve targeting and pharmacokinetics of RNA-based drugs [158]. Although secondary structure of ncRNAs is presumably an obstacle to their development as drugs, chemically modified analogues might be used to overcome the limitation [159]. Hopefully, ncRNA-based treatments will someday be realized as new medicines to prevent onset and extend survival in patients with devastating neurodegenerative diseases.

\section{Abbreviations}

6-OHDA: 6-hydroxy-dopamine; ABCA1: ATP-binding cassette transporter A1; Abhd11-os: MGI Symbol; APP: Amyloid precursor protein; ATP13A2: ATPase type 13A; BACE1: $\beta$-site amyloid precursor protein-cleaving enzyme 1; BC200: Brain cytoplasmic 200 RNA; BDNF: Brain-derived neurotropic factor; BDNF-AS: Brain-derived neurotrophic factor antisense; CACNG5: Calcium voltage-gated channel auxiliary subunit gamma 5; CBP: CREB-binding protein; CCCP: Mitochondrial oxidative phosphorylation uncoupler; CCNA2: Cyclin-A2; CDK5R1: Cyclin-dependent kinase 5 regulatory subunit 1; CHEK1: Checkpoint kinase 1; COREST: REST corepressor 1; DGCR5: DiGeorge syndrome critical region gene 5; EAAT2: excitatory amino acid transport 2; EBF3: B cell factor 3; EBF3-AS: Antisense transcript of EBF3; FMRP: fragile $X$ syndrome protein; Fyn: a Src family tyrosine kinase; FZD3/5: Frizzled 3/5; GDNF: Glial cell-derived neurotrophic factor; GLAST: L-glutamate/L-aspartate transporter; GLT1: Glutamate transporter subtype 1; GPR51: G-proteincoupled-receptor 51; HAR1: Human accelerated region 1; HDAC4: Histone deacetylase 4; HIP1: Huntingtin Interaction Protein 1; Hmgb2: High-mobility group box 2; HMOX1: Heme oxygenase 1; HOTAIR: Hox transcript antisense intergenic RNA; Hsrw: Stress-induced satellite III repeat RNA;

HTT: Hungtingtin; HTT-AS: Huntingtin antisense; IRS-1: Insulin receptor substrate 1; IRS-1 pSer: The insulin receptor substrate 1 at serine residues; KLF2: Kruppel-like factor 2; LPS: Lipopolysaccharide; LRP1: Low-density lipoprotein receptor related protein 1; LRRK2: Leucine-rich repeat kinase 2; MDR1: Multidrug resistance protein 1; MEG3: Maternally expressed 3; mHTT: Mutant HTT; MPP +: methyl-4-phenylpyridinium; MPTP: 1-methyl-4phenyl-1236-tetrahydropyridine; MSN: Striatal medium spiny neurons; MtCK: Mitochondrial creatine kinase; NAT-RAd18: Antisense transcript of RAd18; NATs: Natural antisense transcripts; ncRNACCND1: Antisense transcript of CCND1; NDM29: Neuroblastoma differentiation marker 29; NEAT1: Nuclear Enriched Abundant Transcript 1; NEFH: Neurofilament triplet H protein; NEFM: Neurofilament Triplet M Protein; NLRP3: Nod-like receptor protein 3; NORAD: Noncoding RNA activated by DNA damage; Nrf2: Nuclear factor erythroid 2-related factor 2; PAF1C: CDC73/PAF1 complex; PAK1: p21activated kinase 1; PARK2: Parkin; PARK7: Protein deglycase DJ-1; PAXBP: PAX3/PAX7 binding protein; PCNA: Proliferating cell nuclear antigen; PCR2: polycomb repressive complex 2; PGC-1a: Peroxisome proliferatoractivated receptor- $\gamma$ coactivator; PINK1: PTEN-induced kinase 1; PPARY: $\gamma^{-}$ peroxisome proliferator-activated receptor; PPX: Pramipexole; PRC2: Polycomb repressive complex 2; RANBP10: RAN binding protein 10; REST: Repressor Element 1-Silencing Transcription factor; RGS2 : Regulator of G-protein signaling 2; RhoA: Ras homolog family member A; S6K1: Ribosomal protein S6 kinase B1; SAMP mouse model: A naturally occuring mouse line that displays a phenotype of accelerated aging; sCAGs: small CAG-repeated RNAs; Sirt1: Sirtuin 1, a nicotinamide adenine dinucleotide-dependent deacetylase; SNCA: a-synuclein; SNHG1: Small nucleolar RNA host gene 1; SORL1AS (51A): Antisense of sortilin related receptor 1; TDP43: TAR DNA BINDING PROTEIN; TH: Tyrosine hydroxylase; TLR: Toll-like receptor; TRPM2: Transient receptor potential cation channel subfamily M member 2; TRPM7: Transient receptor potential cation channel subfamily M member 7; TUG1: Taurine Upregulated Gene 1; TUNA: Tcl1 Upstream Neuron-Associated lincRNA; 
UCHL1: Ubiquitin carboxy terminal hydrolase L1; ZBTB11: Zinc Finger and BTB Domain containing 11

\section{Acknowledgements}

We would like to thank Marcus Calkins for his helpful comments during manuscript preparation.

\section{Ethical approval and consent to participate}

Not applicable.

\section{Availability of supporting data}

Not applicable.

\section{Authors' contributions}

HCK and YYW drafted this article, revised it critically and gave final approval of submitted/revised visions.

\section{Funding}

This work was supported by the intramural grants from Academia Sinica (AS106-TP-B13 and AS-SUMMIT-108) and the grants from the Ministry of Science and Technology, Taiwan (MOST 106-0210-01-15-02, MOST 108-3114-Y-001002, and MOST 107-0210-01-19-01) to HC. K.

\section{Consent for publication}

$$
\text { Not applicable. }
$$

\section{Competing interests}

The named authors have no conflicts of interest, financial or otherwise.

\section{Received: 15 November 2019 Accepted: 26 February 2020}

\section{Published online: 07 April 2020}

\section{References}

1. Yao RW, Wang Y, Chen LL. Cellular functions of long noncoding RNAs. Nat Cell Biol. 2019;21(5):542-51.

2. Juźwik CA, Drake S, Zhang Y, Paradis-Isler N, Sylvester A, Amar-Zifkin A, et al microRNA dysregulation in neurodegenerative diseases: a systematic review. Prog Neurobiol. 2019;182:101664.

3. Kay GF, Penny GD, Patel D, Ashworth A, Brockdorff N, Rastan S. Expression of Xist during mouse development suggests a role in the initiation of $X$ chromosome inactivation. Cell. 1993;72(2):171-82.

4. Xiang JF, Yin QF, Chen T, Zhang Y, Zhang XO, Wu Z, et al. Human colorectal cancer-specific CCAT1-L InCRNA regulates long-range chromatin interactions at the MYC locus. Cell Res. 2014;24(5):513-31.

5. Kristensen LS, Andersen MS, Stagsted LW, Ebbesen KK, Hansen TB, Kjems J. The biogenesis, biology and characterization of circular RNAs. Nat Rev Genet. 2019;20(11):675-91.

6. Wu Y-Y, Chiu F-L, Yeh C-S, Kuo H-C. Opportunities and challenges for the use of induced pluripotent stem cells in modelling neurodegenerative disease. Open Biol. 2019;9(1):180177.

7. Chung DW, Rudnicki DD, Yu L, Margolis RL. A natural antisense transcript at the Huntington's disease repeat locus regulates HTT expression. Hum Mol Genet. 2011;20(17):3467-77.

8. Recasens A, Perier C, Sue CM. Role of microRNAs in the regulation of alphaSynuclein expression: a systematic review. Front Mol Neurosci. 2016;9:128.

9. Wimo A, Winblad B, Jonsson L. The worldwide societal costs of dementia: estimates for 2009. Alzheimers Dement. 2010;6(2):98-103.

10. Dols-Icardo O, Garcia-Redondo A, Rojas-Garcia R, Sanchez-Valle R, Noguera A, Gomez-Tortosa E, et al. Characterization of the repeat expansion size in C9orf72 in amyotrophic lateral sclerosis and frontotemporal dementia. Hum Mol Genet. 2014;23(3):749-54.

11. Scotter EL, Chen HJ, Shaw CE. TDP-43 Proteinopathy and ALS: insights into disease mechanisms and therapeutic targets. Neurotherapeutics. 2015;12(2): 352-63.

12. Sang Q, Liu X, Wang L, Qi L, Sun W, Wang W, et al. CircSNCA downregulation by pramipexole treatment mediates cell apoptosis and autophagy in Parkinson's disease by targeting miR-7. Aging (Albany NY). 2018:10(6):1281-93.

13. Quansah E, Peelaerts W, Langston JW, Simon DK, Colca J, Brundin P. Targeting energy metabolism via the mitochondrial pyruvate carrier as a novel approach to attenuate neurodegeneration. Mol Neurodegener. 2018;13(1):28.
14. Fumagalli F, Di Pasquale L, Caffino L, Racagni G, Riva MA. Stress and cocaine interact to modulate basic fibroblast growth factor (FGF-2) expression in rat brain. Psychopharmacology. 2008;196(3):357-64.

15. Warner KD, Hajdin CE, Weeks KM. Principles for targeting RNA with drug-like small molecules. Nat Rev Drug Discov. 2018;17(8):547-58.

16. Mercer TR, Dinger ME, Sunkin SM, Mehler MF, Mattick JS. Specific expression of long noncoding RNAs in the mouse brain. Proc Natl Acad Sci U S A. 2008;105(2):716-21.

17. Belgard TG, Marques AC, Oliver PL, Abaan HO, Sirey TM, HoerderSuabedissen A, et al. A transcriptomic atlas of mouse neocortical layers. Neuron. 2011;71(4):605-16

18. Gruner H, Cortes-Lopez M, Cooper DA, Bauer M, Miura P. CircRNA accumulation in the aging mouse brain. Sci Rep. 2016;6:38907.

19. Douglas AGL. Non-coding RNA in C9orf72-related amyotrophic lateral sclerosis and frontotemporal dementia: A perfect storm of dysfunction. Noncoding RNA Res. 2018;3(4):178-87.

20. Niu M, Xu R, Wang J, Hou B, Xie A. MiR-133b ameliorates axon degeneration induced by MPP(+) via targeting RhoA. Neuroscience. 2016;325:39-49.

21. Kim J, Fiesel FC, Belmonte KC, Hudec R, Wang WX, Kim C, et al. miR-27a and $\mathrm{miR}-27 \mathrm{~b}$ regulate autophagic clearance of damaged mitochondria by targeting PTEN-induced putative kinase 1 (PINK1). Mol Neurodegener. 2016; 11(1):55.

22. Butovsky O, Jedrychowski MP, Cialic R, Krasemann S, Murugaiyan G, Fanek Z et al. Targeting miR-155 restores abnormal microglia and attenuates disease in SOD1 mice. Ann Neurol. 2015;77(1):75-99.

23. Johnson R, Richter N, Jauch R, Gaughwin PM, Zuccato C, Cattaneo E, et al. Human accelerated region 1 noncoding RNA is repressed by REST in Huntington's disease. Physiol Genomics. 2010;41(3):269-74.

24. Johnson $\mathrm{R}$, Teh $\mathrm{CH}$, Jia H, Vanisri RR, Pandey $T$, Lu ZH, et al. Regulation of neural macroRNAs by the transcriptional repressor REST. RNA. 2009;15(1):85-96.

25. Johnson R. Long non-coding RNAs in Huntington's disease neurodegeneration. Neurobiol Dis. 2012;46(2):245-54.

26. Chang KH, Wu YR, Chen CM. Down-regulation of miR-9* in the peripheral leukocytes of Huntington's disease patients. Orphanet J Rare Dis. 2017;12(1):185.

27. Chanda K, Das S, Chakraborty J, Bucha S, Maitra A, Chatterjee R, et al, Altered levels of long NcRNAs Meg3 and Neat1 in cell and animal models of Huntington's disease. RNA Biol. 2018;15(10):1348-63.

28. Sunwoo JS, Lee ST, Im W, Lee M, Byun Jl, Jung KH, et al. Altered expression of the long noncoding RNA NEAT1 in Huntington's disease. Mol Neurobiol. 2017;54(2):1577-86.

29. Cheng C, Spengler RM, Keiser MS, Monteys AM, Rieders JM, Ramachandran $S$, et al. The long non-coding RNA NEAT1 is elevated in polyglutamine repeat expansion diseases and protects from disease gene-dependent toxicities. Hum Mol Genet. 2018;27(24):4303-14.

30. Khalil AM, Guttman M, Huarte M, Garber M, Raj A, Rivea Morales D, et al. Many human large intergenic noncoding RNAs associate with chromatinmodifying complexes and affect gene expression. Proc Natl Acad Sci U S A. 2009:106(28):11667-72

31. Lin N, Chang KY, Li Z, Gates K, Rana ZA, Dang J, et al. An evolutionarily conserved long noncoding RNA TUNA controls pluripotency and neural lineage commitment. Mol Cell. 2014;53(6):1005-19.

32. Francelle L, Galvan L, Gaillard MC, Petit F, Bernay B, Guillermier M, et al. Striatal long noncoding RNA Abhd1 1os is neuroprotective against an N-terminal fragment of mutant huntingtin in vivo. Neurobiol Aging. 2015:36(3):1601.e7-16.

33. Modarresi F, Faghihi MA, Lopez-Toledano MA, Fatemi RP, Magistri M, Brothers SP, et al. Inhibition of natural antisense transcripts in vivo results in gene-specific transcriptional upregulation. Nat Biotechnol. 2012;30(5):453-9.

34. Gutierrez A, Corey-Bloom J, Thomas EA, Desplats P. Evaluation of biochemical and epigenetic measures of peripheral brain-derived Neurotrophic factor (BDNF) as a biomarker in Huntington's disease patients. Front Mol Neurosci. 2019;12:335.

35. Banez-Coronel M, Porta S, Kagerbauer B, Mateu-Huertas E, Pantano L, Ferrer I, et al. A pathogenic mechanism in Huntington's disease involves small CAG-repeated RNAs with neurotoxic activity. PLoS Genet. 2012;8(2):e1002481.

36. Hoss AG, Labadorf A, Latourelle JC, Kartha VK, Hadzi TC, Gusella JF, et al. miR-10b-5p expression in Huntington's disease brain relates to age of onset and the extent of striatal involvement. BMC Med Genet. 2015:8:10.

37. Ban JJ, Chung JY, Lee M, Im W, Kim M. MicroRNA-27a reduces mutant hutingtin aggregation in an in vitro model of Huntington's disease. Biochem Biophys Res Commun. 2017:488(2):316-21. 
38. Reynolds RH, Petersen MH, Willert CW, Heinrich M, Nymann N, Dall M, et al. Perturbations in the p53/miR-34a/SIRT1 pathway in the R6/2 Huntington's disease model. Mol Cell Neurosci. 2018;88:118-29.

39. Gaughwin PM, Ciesla M, Lahiri N, Tabrizi SJ, Brundin P, Bjorkqvist M. HsamiR-34b is a plasma-stable microRNA that is elevated in pre-manifest Huntington's disease. Hum Mol Genet. 2011;20(11):2225-37.

40. Prajapati B, Fatma M, Maddhesiya P, Sodhi MK, Fatima M, Dargar T, et al. Identification and epigenetic analysis of divergent long non-coding RNAs in multilineage differentiation of human neural progenitor cells. RNA Biol. 2019:16(1):13-24.

41. Ghose J, Sinha M, Das E, Jana NR, Bhattacharyya NP. Regulation of miR-146a by RelA/NFkB and p53 in STHdh(Q111)/Hdh(Q111) cells, a cell model of Huntington's disease. PLoS One. 2011;6(8):e23837.

42. Das E, Jana NR, Bhattacharyya NP. MicroRNA-124 targets CCNA2 and regulates cell cycle in STHdh(Q111)/Hdh(Q111) cells. Biochem Biophys Res Commun. 2013;437(2):217-24.

43. Das $E$, Jana NR, Bhattacharyya NP. Delayed cell cycle progression in STHdh(Q111)/Hdh(Q111) cells, a cell model for Huntington's disease mediated by microRNA-19a, microRNA-146a and microRNA-432. Microrna. 2015;4(2):86-100.

44. Kocerha J, Xu Y, Prucha MS, Zhao D, Chan AW. microRNA-128a dysregulation in transgenic Huntington's disease monkeys. Mol. Brain. 2014;7:46.

45. Fukuoka M, Takahashi M, Fujita H, Chiyo T, Popiel HA, Watanabe S, et al. Supplemental treatment for Huntington's disease with miR-132 that is deficient in Huntington's disease brain. Mol Ther Nucleic Acids. 2018;11:79-90.

46. Kunkanjanawan T, Carter RL, Prucha MS, Yang J, Parnpai R, Chan AW. miR196a Ameliorates Cytotoxicity and Cellular Phenotype in Transgenic Huntington's Disease Monkey Neural Cells. PLoS One. 2016;11(9):e0162788.

47. Her LS, Mao SH, Chang CY, Cheng PH, Chang YF, Yang HI, et al. miR-196a enhances neuronal morphology through suppressing RANBP10 to provide Neuroprotection in Huntington's disease. Theranostics. 2017;7(9):2452-62.

48. Cheng PH, Li CL, Chang YF, Tsai SJ, Lai YY, Chan AW, et al. miR-196a ameliorates phenotypes of Huntington disease in cell, transgenic mouse, and induced pluripotent stem cell models. Am J Hum Genet. 2013;93(2):306-12

49. Johnson R, Zuccato C, Belyaev ND, Guest DJ, Cattaneo E, Buckley NJ. A microRNA-based gene dysregulation pathway in Huntington's disease. Neurobiol Dis. 2008;29(3):438-45.

50. Varendi K, Kumar A, Harma MA, Andressoo JO. miR-1, miR-10b, miR-155, and miR-191 are novel regulators of BDNF. Cell Mol Life Sci. 2014;71(22):4443-56.

51. Lee MG, Wynder C, Cooch N, Shiekhattar R. An essential role for CoREST in nucleosomal histone 3 lysine 4 demethylation. Nature. 2005;437(7057):432-5.

52. Hwang JY, Zukin RS. REST, a master transcriptional regulator in neurodegenerative disease. Curr Opin Neurobiol. 2018;48:193-200.

53. Zuccato C, Tartari M, Crotti A, Goffredo D, Valenza M, Conti L, et al. Huntingtin interacts with REST/NRSF to modulate the transcription of NRSEcontrolled neuronal genes. Nat Genet. 2003;35(1):76-83.

54. Jovicic A, Zaldivar Jolissaint JF, Moser R, Silva Santos Mde F, Luthi-Carter R. MicroRNA-22 (miR-22) overexpression is neuroprotective via general antiapoptotic effects and may also target specific Huntington's disease-related mechanisms. PLoS One. 2013;8(1):e54222.

55. Marti E, Pantano L, Banez-Coronel M, Llorens F, Minones-Moyano E, Porta S, et al. A myriad of miRNA variants in control and Huntington's disease brain regions detected by massively parallel sequencing. Nucleic Acids Res. 2010; 38(20):7219-35.

56. Langfelder P, Gao F, Wang N, Howland D, Kwak S, Vogt TF, et al. MicroRNA signatures of endogenous Huntingtin CAG repeat expansion in mice. PLoS One. 2018;13(1):e0190550.

57. Geng Y, Liu X, Liang J, Habiel DM, Kulur V, Coelho AL, et al. PD-L1 on invasive fibroblasts drives fibrosis in a humanized model of idiopathic pulmonary fibrosis. JCl Insight. 2019;4(6).

58. Wang S, Zhang X, Guo Y, Rong H, Liu T. The long noncoding RNA HOTAIR promotes Parkinson's disease by upregulating LRRK2 expression. Oncotarget. 2017:8(15):24449-56.

59. Lin Q, Hou S, Dai Y, Jiang N, Lin Y. LncRNA HOTAIR targets miR-126-5p to promote the progression of Parkinson's disease through RAB3IP. Biol Chem. 2019;400(9):1217-28

60. Liu Y, Lu Z. Long non-coding RNA NEAT1 mediates the toxic of Parkinson's disease induced by MPTP/MPP + via regulation of gene expression. Clin Exp Pharmacol Physiol. 2018;45(8):841-8.

61. Xie SP, Zhou F, Li J, Duan SJ. NEAT1 regulates MPP(+)-induced neuronal injury by targeting miR-124 in neuroblastoma cells. Neurosci Lett. 2019;708:134340.
62. Yan W, Chen ZY, Chen JQ, Chen HM. LncRNA NEAT1 promotes autophagy in MPTP-induced Parkinson's disease through stabilizing PINK1 protein. Biochem Biophys Res Commun. 2018;496(4):1019-24.

63. Ding XM, Zhao L, Qiao HY, Wu SL, Wang XH. Long non-coding RNA-p21 regulates $M P P(+)$-induced neuronal injury by targeting miR-625 and derepressing TRPM2 in SH-SY5Y cells. Chem Biol Interact. 2019;307:73-81.

64. Xu X, Zhuang C, Wu Z, Qiu H, Feng H, Wu J. LincRNA-p21 inhibits cell viability and promotes cell apoptosis in Parkinson's disease through activating alpha-Synuclein expression. Biomed Res Int. 2018;2018:8181374.

65. Qian C, Ye Y, Mao H, Yao L, Sun X, Wang B, et al. Downregulated IncRNASNHG1 enhances autophagy and prevents cell death through the miR-221/ 222 /p27/mTOR pathway in Parkinson's disease. Exp Cell Res. 2019;384(1): 111614

66. Cao B, Wang T, Qu Q, Kang T, Yang Q. Long noncoding RNA SNHG1 promotes Neuroinflammation in Parkinson's disease via regulating miR-7/ NLRP3 pathway. Neuroscience. 2018;388:118-27.

67. Soreq L, Guffanti A, Salomonis N, Simchovitz A, Israel Z, Bergman H, et al. Long non-coding RNA and alternative splicing modulations in Parkinson's leukocytes identified by RNA sequencing. PLoS Comput Biol. 2014;10(3): e1003517.

68. Magee R, Londin E, Rigoutsos I. TRNA-derived fragments as sex-dependent circulating candidate biomarkers for Parkinson's disease. Parkinsonism Relat Disord. 2019;65:203-9.

69. Carrieri C, Forrest AR, Santoro C, Persichetti F, Carninci P, Zucchelli S, et al. Expression analysis of the long non-coding RNA antisense to Uchl1 (AS Uchl1) during dopaminergic cells' differentiation in vitro and in neurochemical models of Parkinson's disease. Front Cell Neurosci. 2015;9:114.

70. Espinoza S, Scarpato M, Damiani D, Manago F, Mereu M, Contestabile A, et al. SINEUP Non-coding RNA Targeting GDNF Rescues Motor Deficits and Neurodegeneration in a Mouse Model of Parkinson's Disease. Mol Ther. 2019.

71. Kim W, Lee Y, McKenna ND, Yi M, Simunovic F, Wang Y, et al. miR-126 contributes to Parkinson's disease by dysregulating the insulin-like growth factor/ phosphoinositide 3-kinase signaling. Neurobiol Aging. 2014;35(7):1712-21.

72. de Mena L, Coto E, Cardo LF, Diaz M, Blazquez M, Ribacoba R, et al. Analysis of the micro-RNA-133 and PITX3 genes in Parkinson's disease. Am J Med Genet B Neuropsychiatr Genet. 2010;153B(6):1234-9.

73. Fragkouli A, Doxakis E. miR-7 and miR-153 protect neurons against MPP(+)-induced cell death via upregulation of mTOR pathway. Front Cell Neurosci. 2014;8:182.

74. Zhang Z, Cheng Y. miR-16-1 promotes the aberrant alpha-synuclein accumulation in parkinson disease via targeting heat shock protein 70 . ScientificWorldJournal. 2014;2014:938348.

75. Gao JX, Li Y, Wang SN, Chen XC, Lin LL, Zhang H. Overexpression of microRNA-183 promotes apoptosis of substantia nigra neurons via the inhibition of OSMR in a mouse model of Parkinson's disease. Int J Mol Med. 2019;43(1):209-20.

76. Cho HJ, Liu G, Jin SM, Parisiadou L, Xie C, Yu J, et al. MicroRNA-205 regulates the expression of Parkinson's disease-related leucine-rich repeat kinase 2 protein. Hum Mol Genet. 2013;22(3):608-20.

77. Yang CP, Zhang ZH, Zhang LH, Rui HC. Neuroprotective role of MicroRNA 22 in a 6-Hydroxydopamine-induced cell model of Parkinson's disease via regulation of its target gene TRPM7. J Mol Neurosci. 2016;60(4):445-52.

78. Kabaria S, Choi DC, Chaudhuri AD, Mouradian MM, Junn E. Inhibition of miR-34b and miR-34c enhances alpha-synuclein expression in Parkinson's disease. FEBS Lett. 2015;589(3):319-25.

79. Xiong $\mathrm{R}$, Wang Z, Zhao Z, Li H, Chen W, Zhang B, et al. MicroRNA-494 reduces DJ-1 expression and exacerbates neurodegeneration. Neurobiol Aging. 2014;35(3):705-14.

80. Dong Y, Han LL, Xu ZX. Suppressed microRNA-96 inhibits iNOS expression and dopaminergic neuron apoptosis through inactivating the MAPK signaling pathway by targeting CACNG5 in mice with Parkinson's disease. Mol Med. 2018;24(1):61.

81. Dauer W, Przedborski S. Parkinson's disease: mechanisms and models. Neuron. 2003;39(6):889-909.

82. Belrose JC, Jackson MF. TRPM2: a candidate therapeutic target for treating neurological diseases. Acta Pharmacol Sin. 2018;39(5):722-32.

83. Zhang T, Pang P, Fang Z, Guo Y, Li H, Li X, et al. Expression of BC1 impairs spatial learning and memory in Alzheimer's disease via APP translation. Mol Neurobiol. 2018;55(7):6007-20.

84. Li H, Zheng L, Jiang A, Mo Y, Gong Q. Identification of the biological affection of long noncoding RNA BC200 in Alzheimer's disease. Neuroreport. 2018;29(13):1061-7. 
85. Feng L, Liao YT, He JC, Xie CL, Chen SY, Fan HH, et al. Plasma long noncoding RNA BACE1 as a novel biomarker for diagnosis of Alzheimer disease. BMC Neurol. 2018;18(1):4.

86. Mus E, Hof PR, Tiedge H. Dendritic BC200 RNA in aging and in Alzheimer's disease. Proc Natl Acad Sci U S A. 2007;104(25):10679-84.

87. Wang $X$, Zhang $M$, Liu $H$. LncRNA17A regulates autophagy and apoptosis of SH-SY5Y cell line as an in vitro model for Alzheimer's disease. Biosci Biotechnol Biochem. 2019;83(4):609-21.

88. Massone S, Vassallo I, Fiorino G, Castelnuovo M, Barbieri F, Borghi R, et al. 17A, a novel non-coding RNA, regulates GABA B alternative splicing and signaling in response to inflammatory stimuli and in Alzheimer disease. Neurobiol Dis. 2011;41(2):308-17.

89. Yi J, Chen B, Yao X, Lei Y, Ou F, Huang F. Upregulation of the IncRNA MEG3 improves cognitive impairment, alleviates neuronal damage, and inhibits activation of astrocytes in hippocampus tissues in Alzheimer's disease through inactivating the PI3K/Akt signaling pathway. J Cell Biochem. 2019; 120(10):18053-65.

90. Jiang Q, Shan K, Qun-Wang X, Zhou RM, Yang H, Liu C, et al. Long noncoding RNA-MIAT promotes neurovascular remodeling in the eye and brain. Oncotarget. 2016;7(31):49688-98.

91. Ke S, Yang Z, Yang F, Wang $X$, Tan J, Liao B. Long noncoding RNA NEAT1 aggravates Abeta-induced neuronal damage by targeting miR-107 in Alzheimer's disease. Yonsei Med J. 2019;60(7):640-50.

92. Zhao MY, Wang GQ, Wang NN, Yu QY, Liu RL, Shi WQ. The long-non-coding RNA NEAT1 is a novel target for Alzheimer's disease progression via miR124/BACE1 axis. Neurol Res. 2019;41(6):489-97.

93. Spreafico M, Grillo B, Rusconi F, Battaglioli E, Venturin M. Multiple Layers of CDK5R1 Regulation in Alzheimer's Disease Implicate Long Non-Coding RNAs. Int J Mol Sci. 2018;19(7).

94. Polesskaya O, Kananykhina E, Roy-Engel AM, Nazarenko O, Kulemzina I, Baranova A, et al. The role of Alu-derived RNAs in Alzheimer's and other neurodegenerative conditions. Med Hypotheses. 2018;115:29-34.

95. Faghihi MA, Wahlestedt C. Regulatory roles of natural antisense transcripts. Nat Rev Mol Cell Biol. 2009;10(9):637-43.

96. Faghihi MA, Zhang M, Huang J, Modarresi F, Van der Brug MP, Nalls MA, et al. Evidence for natural antisense transcript-mediated inhibition of microRNA function. Genome Biol. 2010;11(5):R56.

97. Gu C, Chen C, Wu R, Dong T, Hu X, Yao Y, et al. Long noncoding RNA EBF3AS promotes neuron apoptosis in Alzheimer's disease. DNA Cell Biol. 2018; 37(3):220-6.

98. Ciarlo E, Massone S, Penna I, Nizzari M, Gigoni A, Dieci G, et al. An intronic ncRNA-dependent regulation of SORL1 expression affecting Abeta formation is upregulated in post-mortem Alzheimer's disease brain samples. Dis Model Mech. 2013;6(2):424-33.

99. Zhang L, Fang Y, Cheng X, Lian YJ, Xu HL. Silencing of long noncoding RNA SOX21-AS1 relieves neuronal oxidative stress injury in mice with Alzheimer's disease by Upregulating FZD3/5 via the Wnt signaling pathway. Mol Neurobiol. 2019;56(5):3522-37.

100. Parenti R, Paratore S, Torrisi A, Cavallaro S. A natural antisense transcript against Rad18, specifically expressed in neurons and upregulated during beta-amyloid-induced apoptosis. Eur J Neurosci. 2007;26(9):2444-57.

101. Holtzman DM, Herz J, Bu G. Apolipoprotein E and apolipoprotein E receptors: normal biology and roles in Alzheimer disease. Cold Spring Harb Perspect Med. 2012;2(3):a006312.

102. Yamanaka Y, Faghihi MA, Magistri M, Alvarez-Garcia O, Lotz M, Wahlestedt C. Antisense RNA controls LRP1 sense transcript expression through interaction with a chromatin-associated protein, HMGB2. Cell Rep. 2015; 11(6):967-76.

103. Magistri M, Velmeshev D, Makhmutova M, Faghihi MA. Transcriptomics profiling of Alzheimer's disease reveal neurovascular defects, altered amyloid-beta homeostasis, and deregulated expression of long noncoding RNAs. J Alzheimers Dis. 2015;48(3):647-65.

104. Lehmann SM, Kruger C, Park B, Derkow K, Rosenberger K, Baumgart J, et al. An unconventional role for miRNA: let-7 activates toll-like receptor 7 and causes neurodegeneration. Nat Neurosci. 2012;15(6):827-35.

105. Wang H, Liu J, Zong Y, Xu Y, Deng W, Zhu H, et al. miR-106b aberrantly expressed in a double transgenic mouse model for Alzheimer's disease targets TGF-beta type II receptor. Brain Res. 2010;1357:166-74.

106. Liu W, Zhao J, Lu G. miR-106b inhibits tau phosphorylation at Tyr18 by targeting Fyn in a model of Alzheimer's disease. Biochem Biophys Res Commun. 2016:478(2):852-7.
107. Liu Y, Zhang Y, Liu P, Bai H, Li X, Xiao J, et al. MicroRNA-128 knockout inhibits the development of Alzheimer's disease by targeting PPARgamma in mouse models. Eur J Pharmacol. 2019;843:134-44.

108. Smith PY, Hernandez-Rapp J, Jolivette F, Lecours C, Bisht K, Goupil C, et al. miR-132/212 deficiency impairs tau metabolism and promotes pathological aggregation in vivo. Hum Mol Genet. 2015;24(23):6721-35.

109. Basavaraju M, de Lencastre A. Alzheimer's disease: presence and role of microRNAs. Biomol Concepts. 2016;7(4):241-52.

110. Sierksma A, Lu A, Salta E, Vanden Eynden E, Callaerts-Vegh Z, D'Hooge R, et al. Deregulation of neuronal miRNAs induced by amyloid-beta or TAU pathology. Mol Neurodegener. 2018;13(1):54.

111. Moncini S, Lunghi M, Valmadre A, Grasso M, Del Vescovo V, Riva P, et al. The miR-15/107 family of microRNA genes regulates CDK5R1/p35 with implications for Alzheimer's disease pathogenesis. Mol Neurobiol. 2017;54(6):4329-42.

112. Parsi S, Smith PY, Goupil C, Dorval V, Hebert SS. Preclinical evaluation of miR-15/107 family members as multifactorial drug targets for Alzheimer's disease. Mol Ther Nucleic Acids. 2015;4:e256.

113. Zhong Z, Yuan K, Tong X, Hu J, Song Z, Zhang G, et al. MiR-16 attenuates beta-amyloid-induced neurotoxicity through targeting beta-site amyloid precursor protein-cleaving enzyme 1 in an Alzheimer's disease cell model. Neuroreport. 2018;29(16):1365-72.

114. Higaki S, Muramatsu M, Matsuda A, Matsumoto K, Satoh Jl, Michikawa M, et al. Defensive effect of microRNA-200b/c against amyloid-beta peptide-induced toxicity in Alzheimer's disease models. PLoS One. 2018;13(5):e0196929.

115. Duan Q, Si E. MicroRNA-25 aggravates Abeta1-42-induced hippocampal neuron injury in Alzheimer's disease by downregulating KLF2 via the Nrf2 signaling pathway in a mouse model. J Cell Biochem. 2019;120(9):15891-905.

116. Hebert SS, Horre K, Nicolai L, Bergmans B, Papadopoulou AS, Delacourte A, et al. MicroRNA regulation of Alzheimer's amyloid precursor protein expression. Neurobiol Dis. 2009;33(3):422-8.

117. Yang G, Song Y, Zhou X, Deng Y, Liu T, Weng G, et al. MicroRNA-29c targets beta-site amyloid precursor protein-cleaving enzyme 1 and has a neuroprotective role in vitro and in vivo. Mol Med Rep. 2015;12(2):3081-8.

118. Kim J, Yoon H, Horie T, Burchett JM, Restivo JL, Rotllan N, et al. microRNA-33 regulates ApoE Lipidation and amyloid-beta metabolism in the brain. J Neurosci. 2015;35(44):14717-26.

119. Wang $X$, Liu $P$, Zhu H, Xu Y, Ma C, Dai $X$, et al. miR-34a, a microRNA upregulated in a double transgenic mouse model of Alzheimer's disease, inhibits bcl2 translation. Brain Res Bull. 2009;80(4-5):268-73.

120. Jian C, Lu M, Zhang Z, Liu L, Li X, Huang F, et al. miR-34a knockout attenuates cognitive deficits in APP/PS1 mice through inhibition of the amyloidogenic processing of APP. Life Sci. 2017;182:104-11.

121. Shi R, Zhang S, Cheng G, Yang X, Zhao N, Chen C. Ginsenoside Rg1 and Acori Graminei Rhizoma attenuates neuron cell apoptosis by promoting the expression of miR-873-5p in Alzheimer's disease. Neurochem Res. 2018:43(8):1529-38.

122. Qian Q, Zhang J, He FP, Bao WX, Zheng TT, Zhou DM, et al. Downregulated expression of microRNA-338-5p contributes to neuropathology in Alzheimer's disease. FASEB J. 2019;33(3):4404-17.

123. Karran E, Mercken M, De Strooper B. The amyloid cascade hypothesis for Alzheimer's disease: an appraisal for the development of therapeutics. Nat Rev Drug Discov. 2011;10(9):698-712.

124. Fandos N, Perez-Grijalba V, Pesini P, Olmos S, Bossa M, Villemagne VL, et al. Plasma amyloid beta 42/40 ratios as biomarkers for amyloid beta cerebral deposition in cognitively normal individuals. Alzheimers Dement (Amst). 2017;8:179-87.

125. Shu B, Zhang X, Du G, Fu Q, Huang L. MicroRNA-107 prevents amyloidbeta-induced neurotoxicity and memory impairment in mice. Int J Mol Med. 2018;41(3):1665-72.

126. Du X, Huo X, Yang Y, Hu Z, Botchway BOA, Jiang Y, et al. miR-124 downregulates BACE 1 and alters autophagy in APP/PS1 transgenic mice. Toxicol Lett. 2017:280:195-205.

127. Chen M, Guerrero AD, Huang L, Shabier Z, Pan M, Tan TH, et al. Caspase-9induced mitochondrial disruption through cleavage of anti-apoptotic BCL-2 family members. J Biol Chem. 2007;282(46):33888-95.

128. Fang YS, Tsai KJ, Chang YJ, Kao P, Woods R, Kuo PH, et al. Full-length TDP43 forms toxic amyloid oligomers that are present in frontotemporal lobar dementia-TDP patients. Nat Commun. 2014:5:4824.

129. Freibaum BD, Lu YB, Lopez-Gonzalez R, Kim NC, Almeida S, Lee KH, et al. GGGGCC repeat expansion in C9orf72 compromises nucleocytoplasmic transport. Nature. 2015;525(7567):129.

130. Goodman LD, Prudencio M, Kramer NJ, Martinez-Ramirez LF, Srinivasan AR, Lan M, et al. Toxic expanded GGGGCC repeat transcription is 
mediated by the PAF1 complex in C9orf72-associated FTD. Nat Neurosci. 2019;22(6):863-74.

131. Chung CY, Berson A, Kennerdell JR, Sartoris A, Unger T, Porta S, et al. Aberrant activation of non-coding RNA targets of transcriptional elongation complexes contributes to TDP-43 toxicity. Nat Commun. 2018;9(1):4406.

132. Lagier-Tourenne C, Polymenidou M, Hutt KR, Vu AQ, Baughn M, Huelga SC, et al. Divergent roles of ALS-linked proteins FUS/TLS and TDP-43 intersect in processing long pre-mRNAs. Nat Neurosci. 2012;15(11):1488-97.

133. Tollervey JR, Curk T, Rogelj B, Briese M, Cereda M, Kayikci M, et al. Characterizing the RNA targets and position-dependent splicing regulation by TDP-43. Nat Neurosci. 2011;14(4):452-8.

134. An H, Skelt L, Notaro A, Highley JR, Fox AH, La Bella V, et al. ALS-linked FUS mutations confer loss and gain of function in the nucleus by promoting excessive formation of dysfunctional paraspeckles. Acta Neuropathol Commun. 2019;7(1):7.

135. Nishimoto Y, Nakagawa S, Hirose T, Okano HJ, Takao M, Shibata S, et al. The long non-coding RNA nuclear-enriched abundant transcript 1_2 induces paraspeckle formation in the motor neuron during the early phase of amyotrophic lateral sclerosis. Mol Brain. 2013;6:31.

136. Ivanov P, O'Day E, Emara MM, Wagner G, Lieberman J, Anderson P. Gquadruplex structures contribute to the neuroprotective effects of angiogenin-induced tRNA fragments. Proc Natl Acad Sci U S A. 2014; 111(51):18201-6.

137. Wang RH, Sengupta K, Li C, Kim HS, Cao L, Xiao C, et al. Impaired DNA damage response, genome instability, and tumorigenesis in SIRT1 mutant mice. Cancer Cell. 2008;14(4):312-23.

138. Biscarini S, Capauto D, Peruzzi G, Lu L, Colantoni A, Santini T, et al. Characterization of the IncRNA transcriptome in mESC-derived motor neurons: implications for FUS-ALS. Stem Cell Res. 2018;27:172-9.

139. Errichelli L, Dini Modigliani S, Laneve P, Colantoni A, Legnini I, Capauto D, et al. FUS affects circular RNA expression in murine embryonic stem cellderived motor neurons. Nat Commun. 2017:8:14741.

140. Gagliardi S, Zucca S, Pandini C, Diamanti L, Bordoni M, Sproviero D, et al. Long non-coding and coding RNAs characterization in peripheral blood mononuclear cells and spinal cord from amyotrophic lateral sclerosis patients. Sci Rep. 2018;8(1):2378.

141. Chen H, Qian K, Du Z, Cao J, Petersen A, Liu H, et al. Modeling ALS with iPSCs reveals that mutant SOD1 misregulates neurofilament balance in motor neurons. Cell Stem Cell. 2014;14(6):796-809.

142. Dardiotis E, Aloizou AM, Siokas V, Patrinos GP, Deretzi G, Mitsias P, et al. The role of MicroRNAs in patients with amyotrophic lateral sclerosis. J Mol Neurosci. 2018;66(4):617-28.

143. Rohm M, May C, Marcus K, Steinbach S, Theis V, Theiss C, et al. The microRNA miR-375-3p and the tumor suppressor NDRG2 are involved in sporadic amyotrophic lateral sclerosis. Cell Physiol Biochem. 2019;52(6):1412-26.

144. De Santis R, Santini L, Colantoni A, Peruzzi G, de Turris V, Alfano V, et al. FUS mutant human Motoneurons display altered Transcriptome and microRNA pathways with implications for ALS pathogenesis. Stem Cell Reports. 2017; 9(5):1450-62.

145. Tung YT, Lu YL, Peng KC, Yen YP, Chang M, Li J, et al. Mir-17 approximately 92 governs motor neuron subtype survival by mediating nuclear PTEN. Cell Rep. 2015;11(8):1305-18.

146. Tung YT, Peng KC, Chen YC, Yen YP, Chang M, Thams S, et al. Mir-17 approximately 92 confers motor neuron subtype differential resistance to ALS-associated degeneration. Cell Stem Cell. 2019:25(2):193-209.e7.

147. Koval ED, Shaner C, Zhang P, du Maine X, Fischer K, Tay J, et al. Method for widespread microRNA-155 inhibition prolongs survival in ALS-model mice. Hum Mol Genet. 2013;22(20):4127-35.

148. Hoye ML, Regan MR, Jensen LA, Lake AM, Reddy LV, Vidensky S, et al. Motor neuron-derived microRNAs cause astrocyte dysfunction in amyotrophic lateral sclerosis. Brain. 2018;141(9):2561-75.

149. Waller R, Goodall EF, Milo M, Cooper-Knock J, Da Costa M, Hobson E, et al. Serum miRNAs miR-206, 143-3p and 374b-5p as potential biomarkers for amyotrophic lateral sclerosis (ALS). Neurobiol Aging. 2017;55:123-31.

150. Vazquez-Arango P, Vowles J, Browne C, Hartfield E, Fernandes HJ, Mandefro $B$, et al. Variant U1 snRNAs are implicated in human pluripotent stem cell maintenance and neuromuscular disease. Nucleic Acids Res. 2016;44(22): 10960-73.

151. Li PP, Sun X, Xia G, Arbez N, Paul S, Zhu S, et al. ATXN2-AS, a gene antisense to ATXN2, is associated with spinocerebellar ataxia type 2 and amyotrophic lateral sclerosis. Ann Neurol. 2016;80(4):600-15.
152. Schoch KM, Miller TM. Antisense oligonucleotides: translation from mouse models to human neurodegenerative diseases. Neuron. 2017;94(6):1056-70.

153. Yu CY, Kuo HC. The emerging roles and functions of circular RNAs and their generation. J Biomed Sci. 2019;26(1):29.

154. Salta E, De Strooper B. microRNA-132: a key noncoding RNA operating in the cellular phase of Alzheimer's disease. FASEB J. 2017;31(2):424-33.

155. Gawronski KAB, Kim J. Single cell transcriptomics of noncoding RNAs and their cell-specificity. Wiley Interdiscip Rev RNA. 2017;8(6).

156. Wang P, Tang W, Li Z, Zou Z, Zhou Y, Li R, et al. Mapping spatial transcriptome with light-activated proximity-dependent RNA labeling. Nat Chem Biol. 2019.

157. Matsui M, Corey DR. Non-coding RNAs as drug targets. Nat Rev Drug Discov. 2016;16:167.

158. Kole R, Krainer AR, Altman S. RNA therapeutics: beyond RNA interference and antisense oligonucleotides. Nat Rev Drug Discov. 2012;11(2):125-40.

159. Bernat $V$, Disney MD. RNA structures as mediators of neurological diseases and as drug targets. Neuron. 2015:87(1):28-46.

\section{Publisher's Note}

Springer Nature remains neutral with regard to jurisdictional claims in published maps and institutional affiliations.

Ready to submit your research? Choose BMC and benefit from:

- fast, convenient online submission

- thorough peer review by experienced researchers in your field

- rapid publication on acceptance

- support for research data, including large and complex data types

- gold Open Access which fosters wider collaboration and increased citations

- maximum visibility for your research: over $100 \mathrm{M}$ website views per year

At $\mathrm{BMC}$, research is always in progress.

Learn more biomedcentral.com/submissions 